Article

\title{
HOCl Responsive Lanthanide Complexes Using Hydroquinone Caging Units
}

\author{
Elena Del Giorgio and Thomas Just Sørensen * (D) \\ Nano-Science Center \& Department of Chemistry, University of Copenhagen, Universitetsparken5, \\ 2100 København Ø, Denmark; EXD942@student.bham.ac.uk \\ * Correspondence: TJS@chem.ku.dk
}

Academic Editor: Eszter Borbas

Received: 30 March 2020; Accepted: 18 April 2020; Published: 23 April 2020

check for updates

\begin{abstract}
Redox biology is still looking for tools to monitor redox potential in cellular biology and, despite a large and sustained effort, reliable molecular probes have yet to emerge. In contrast, molecular probes for reactive oxygen and nitrogen have been widely explored. In this manuscript, three kinetically inert lanthanide complexes that selectively react with hypochlorous acid are prepared and characterized. The design is based on 1,4,7,10-tetraazacyclododecane-1,4,7-triacetic acid (DO3A) and 1,4,7,10-tetraazacyclododecane-1,7-diacetic acid (DO2A) ligands appended with one or two redox active hydroquinone derived arms, thereby forming octadentate ligands ideally suited to complex trivalent lanthanide ions. The three complexes are found to react selectively with hypochlorous acid to form highly symmetric lanthanide(III) 1,4,7,10-tetraazacyclododecane-1,4,7,10-tetraacedic acid (DOTA) complexes. The conversion of the probe to [Ln.DOTA $]^{-}$is followed by luminescence, absorption, and NMR spectroscopy in a model system comprised of a Triton-X modified HEPES buffer. It was concluded that the design principle works, and that simple caging units like hydroquinones can work well in conjugation with lanthanide(III) complexes.
\end{abstract}

Keywords: lanthanide coordination chemistry; lanthanide luminescence; responsive molecular probes; ROS probes; reactive oxygen species

\section{Introduction}

Reactive Oxygen Species (ROS), and Reactive Nitrogen Species (RNS) [1-3], are classes of compounds that include one- or two-electrons oxidants and play essential roles in living organisms $[1,2]$. The most relevant $\mathrm{ROS}$ originate from a cascade started by the one electron reduction of $\mathrm{O}_{2}$ giving the superoxide radical $\left(\mathrm{O}_{2}^{-}\right)$by means of either NADPH oxidases (NOXs) or by leakage in the electron transport chain inside the mitochondria [1,3-8]. Superoxide Dismutase (SOD) is responsible for the conversion of superoxide into hydrogen peroxide $\left(\mathrm{H}_{2} \mathrm{O}_{2}\right)$ which, in turn, can either undergo a Fenton reaction in the presence of $\mathrm{Fe}^{2+}\left(\mathrm{or}^{2+} \mathrm{Cu}^{2+}\right.$ to give the hydroxyl radical $\mathrm{OH}$ or convert to hypochlorous acid by action of Myeloperoxidase (MPO). ROS play numerous and diverse roles in biology: Biomolecules are responsive to redox conditions and many biological processes are regulated by redox chemistry [1,2,6,7]; although the first understanding of ROS concerned either their deleterious action against lipids, proteins and nucleic acids or their role as antimicrobial agents, the importance of these reactive molecules has recently been revised, spurring the need for better probes to detect them $[4,9,10]$. Given the key role of ROS in biology, many methods have been developed in order to detect them. Among these, mass spectrometry and a plethora of fluorescent and luminescent probes have been proposed over the years [4,11-14]; these probes have also been conjugated to units (peptides or TTP) that can target specific organelles [4]; however, because of the complexity of both living organisms and redox processes in vivo, the selective and reliable detection of ROS has 
proved tricky $[9,15,16]$. Here, we consider luminescent probes for ROS detection that are based on lanthanide(III) luminescence [9,17].

Lanthanide ions possess unique luminescence properties [18]: Lanthanide(III) ions gives rise to high sensitivity even at low concentrations [19], have sharp and characteristic emission bands, and long luminescent lifetimes in the order of $\mu$ s-ms $[18,20]$. The excited states of lanthanide(III) ions are not quenched by $\mathrm{O}_{2}$ and the distinctive and sharp bands boost both signal to noise ratio and sensitivity to analytes. Additionally, DOTA-like lanthanide(III) complexes are fully water soluble, non-toxic and inert in physiological conditions [21]. In a typical probe design, the $\mathrm{Ln}^{3+}$ ion is coordinated to a chelator to avoid release of the toxic free ion in the media and to confer the desired features $[18,22,23]$. Macrocycles like DOTA and its derivatives are more rigid and can form complexes with higher kinetic inertness than open chain chelators [22,24]. Thanks to the kinetic inertness, these complexes can be seen as molecular building blocks and can be linked to different units [23]. The sensing of an analyte can arise from either direct coordination of the analyte to the lanthanide ion centre or from binding/reaction of the analyte with a responsive unit on the chelator. Lanthanide-based probes have been developed to detect an array of analytes [25], e.g., metal ions [26-28], anions [29], ATP [30-34], ROS [13,35,36], and $\mathrm{pH}[37,38]$.

The majority of molecular probes for Reactive Oxygen and Nitrogen Species (RONS) are based on organic dyes, although some examples of lanthanide(III)-based probes have been reported [11,39-43]. Most probes are based on a cage on/off mechanisms: the cage acts as a leaving group upon reaction with the RONS, and in the lanthanide(III)-based probes, the cage blocks the energy transfer from an antenna to the lanthanide centre. When the cage reacts with the RONS, it is cleaved and the antenna is free to transfer energy to the lanthanide(III) centre [44]. Examples of caging units are pinacol boronic esters [36,45], P-aminophenoxy groups [13,46], and dinitrophenyl groups [47], and probes based on these are reported as selective for $\mathrm{H}_{2} \mathrm{O}_{2}$ and hROS (Highly Reactive Oxygen Species, $\mathrm{HOCl}$ and ${ }^{\circ} \mathrm{OH}$ ). Borbas et al. developed a versatile platform built around the deprotection of a coumarin, thus unlocking its sensitization activity towards $\mathrm{Eu}^{3+}$ [45]. Another approach to the design of responsive complexes is the in situ formation of an antenna upon reaction with the ROS. Pierre et al. developed a library of pre-antennas based on aromatic acids or amides; these are hydroxilated in the presence of ${ }^{\circ} \mathrm{OH}$ and coordinate to a Tb.DO3A complex, thus enhancing the luminescence intensity [48]. Finally, a ferrocene appended Eu.DO3A complex prepared by Faulkner should be mentioned. This probe reversibly responds to redox processes [49]. The relevance of this probe is that, unlike the ones reported here, it does not depend on an irreversible process. The advantage of a reversible detection is that saturation of the probe is avoided and a continuous monitoring of the system's redox state would be feasible $[9,50,51]$.

In this work, we also adopt a design based on a cage, although exploiting a different mode of action. The complexes shown in Figure 1 all carry a hydroquinone cage that is released upon reaction with hypochlorous acid forming quinone and the same fully symmetrical [Ln.DOTA $]^{-}$complex, see Scheme 1, a transformation that can be followed using luminescence, absorption, and NMR spectroscopy. The results presented here validate the design concept, and further show that the incorporation of the caging group in a lanthanide(III) complex significantly reduces the reactivity. Finally, it should be noted that the complexes explored here, does not incorporate an antenna chromophore. While this does not constitute an issue in our experiments, it limits the applicability of the complexes studied as molecular probes. 


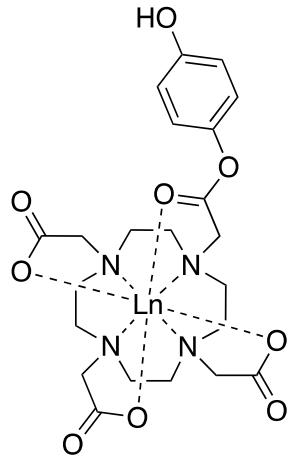

Ln.L1

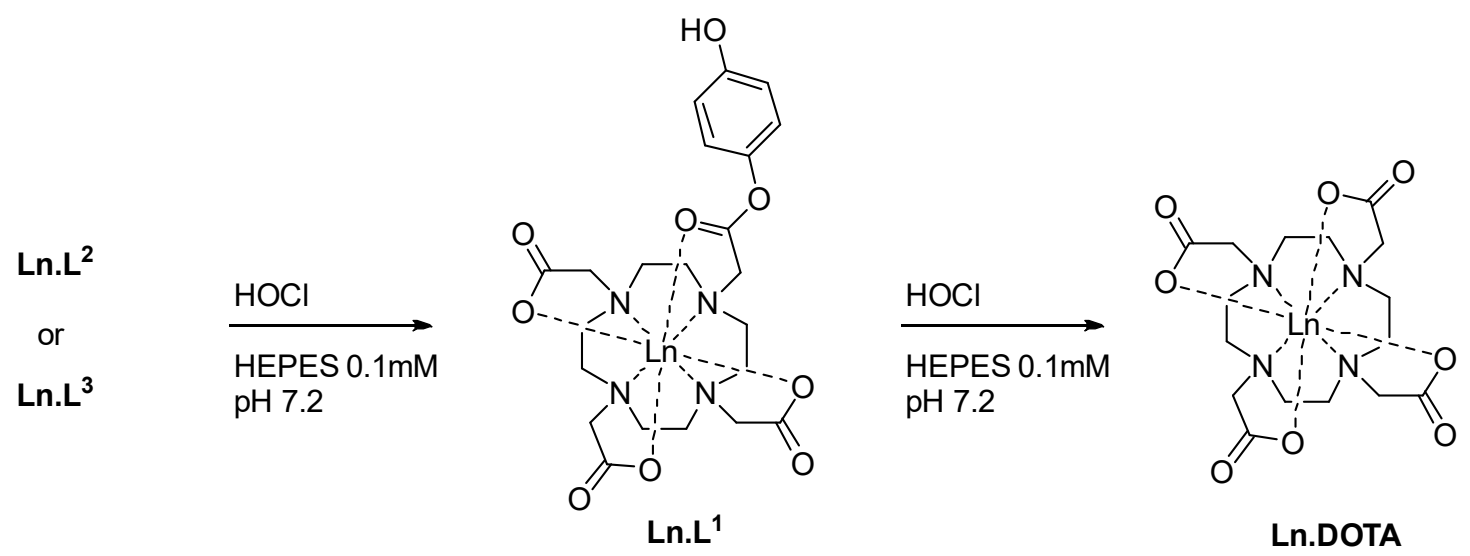

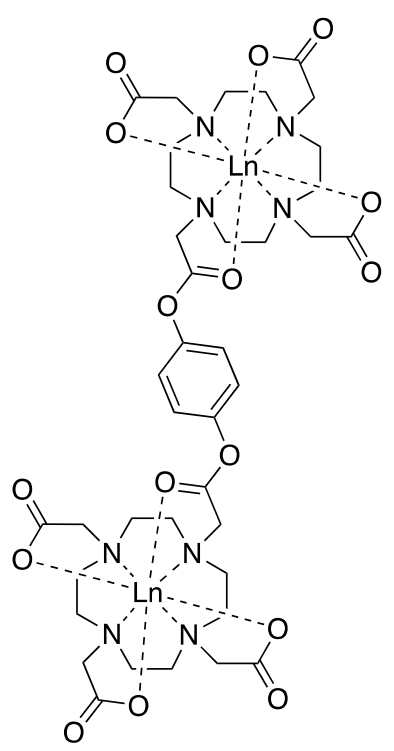

Ln. L ${ }^{2}$

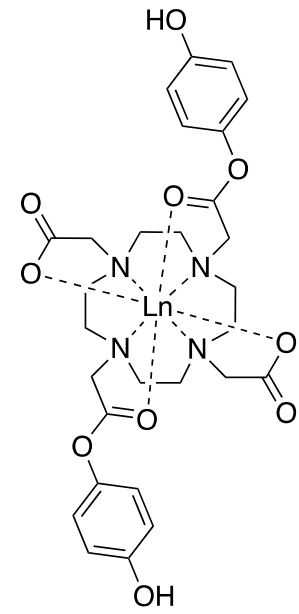

$\operatorname{Ln} \cdot \mathrm{L}^{3}$

Figure 1. Europium(III) and terbium(III) complexes synthesized and investigated.

Scheme 1. Reaction of lanthanide complexes Ln. $\mathbf{L}^{1}$, Ln. $\mathbf{L}^{2}$, and $\mathbf{L n} . \mathrm{L}^{3}$ with hypochlorous acid.

\section{Results and Discussion}

We designed and synthesized three different ligands and prepared their europium(III) and terbium(III) complexes. Considering the three lanthanide(III) complexes $\mathbf{L n} \mathbf{L}^{\mathbf{1}}$ and $\mathbf{L n} \cdot \mathbf{L}^{\mathbf{2}}$ are inherently different from $\mathbf{L n} \cdot \mathbf{L}^{3}$ as the former two are based on the 1,4,7,10-tetraazacyclododecane-1,4,7-triacetic acid (DO3A) scaffold, while the latter is a 1,4,7,10-tetraazacyclododecane-1,7-diacetic acid (DO2A) derivative. The symmetry of the complexes is different, which is expected to be reflected in both NMR and luminescence spectra. Finally, neither of the complexes contains a chromophore, which infers that the relatively inefficient direct excitation into the lanthanide(III) excited state manifold is required if these complexes are to be used as molecular probes.

Considering the three complexes as reactive probes for RONS, there are clear differences that are probed by using these structures. Where $\mathrm{Ln} \mathbf{L}^{\mathbf{1}}$ and $\mathrm{Ln}_{\mathrm{L}} \mathrm{L}^{3}$ both carry mono-esters of hydroquinone, one and two respectively, $\mathrm{Ln} . \mathrm{L}^{2}$ has two lanthanide binding pockets on a di-ester of hydroquinone.

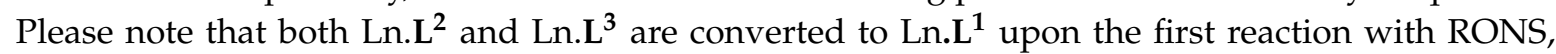
see Scheme 1. Thus, the reactivity of the two hydroquinone esters can be compared, and it can be concluded if the incorporation of subsequent un-caging is a viable route towards higher selectivity. To perform these comparisons, a reliable testbed for the reaction between RONS and the lanthanide(III) complexes was required. 


\subsection{Oxidation Testbed}

To investigate the reaction between RONS and various probes, we tested several solvent and buffer systems. We tested using hydroquinone and the naturally occurring antioxidant $\alpha$-tocopherol in order to simulate the different solubilities and reactivities of various probes. We selected to work at neutral $\mathrm{pH}$ as the end target is probes for molecular biology. Figure 2 shows the results obtained in our optimized buffer system which consists of 100 mM HEPES buffer with 1-3\% Triton X-100 depending on the lipophilicity of the probes investigated. These conditions provide beautiful absorption spectra, where the oxidation of hydroquinone and $\alpha$-tocopherol can be followed. Please note that full conversion is achieved when 1.5-2.0 equivalents of hypochlorous acid have been added.

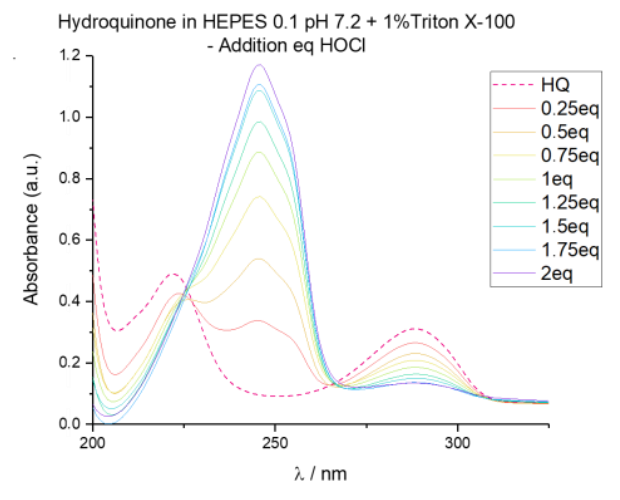

(a)

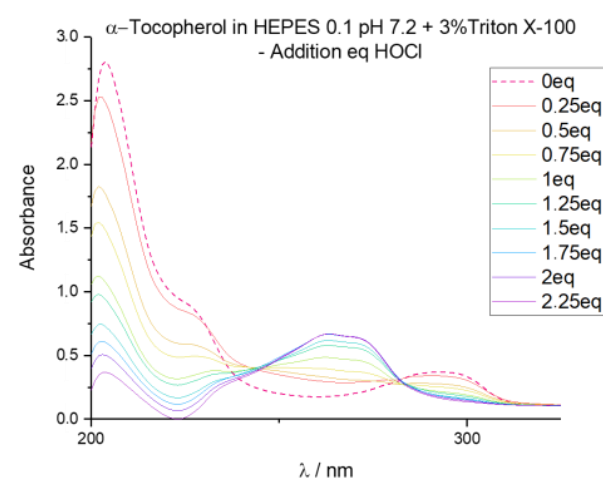

(c)<smiles>O=S(=O)(O)CCN1CCN(CCO)CC1</smiles>

HEPES

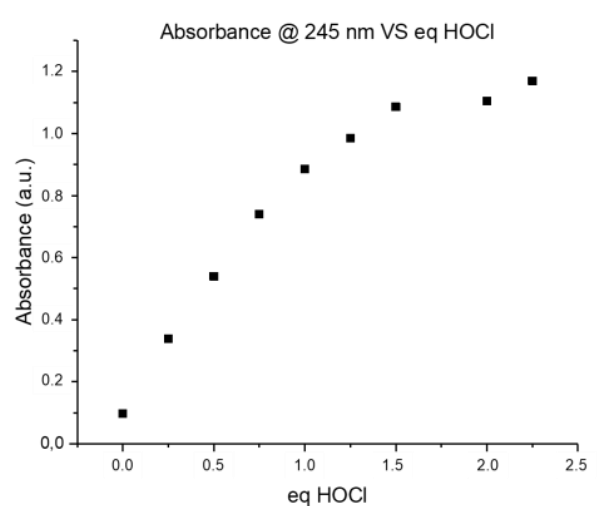

(b)

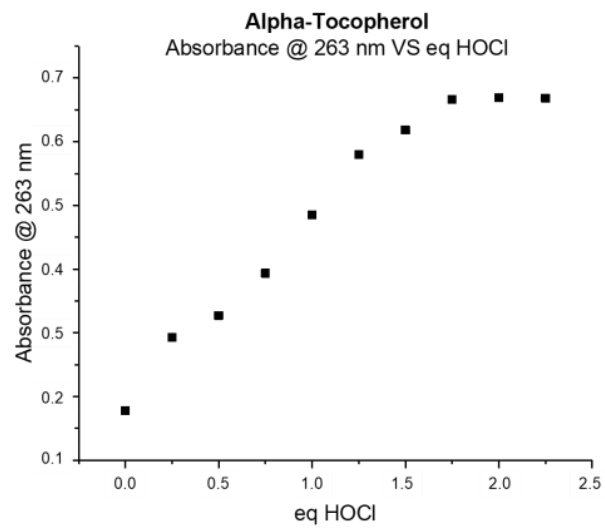

(d)<smiles>CCOc1ccc(C(C)(C)CC(C)(C)C)cc1</smiles>

Triton X-100

(e)

Figure 2. Oxidation test bed performance. (a) Absorption spectra of hydroquinone upon addition of hypochlorous acid. (b) Plot of the absorbance at $245 \mathrm{~nm}$ versus equivalents of added hypochlorous acid for hydroquinone oxidation. (c) Absorption spectra of $\alpha$-tocopherol upon addition of hypochlorous acid. (d) Plot of the absorbance at $263 \mathrm{~nm}$ versus equivalents of added hypochlorous acid for $\alpha$-tocopherol oxidation. (e) Molecular structures of HEPES and Triton X-100. 


\subsection{Synthesis}

The target molecules, shown in Figure 1, are made from the four building blocks shown in Figure 3. The pendant arms $\mathbf{1}$ and $\mathbf{3}$ are obtained via nucleophilic substitution reactions between chloroacetyl chloride and hydroquinone in high yields as white crystals and ice white flakes, respectively (Scheme 2). Protection of the phenol unit in $\mathbf{1}$ is carried out with tert-butyldimethylsilyl chloride and N-methyl imidazole in DMF to give the protected pendant arm 2 as a colourless oil in $64 \%$ yield after purification.<smiles>CCOc1ccc(OC(=O)CCl)cc1</smiles>

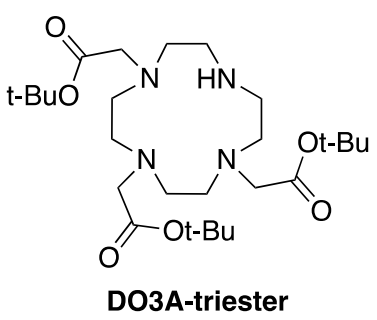<smiles>CCCCN1CCNCCN(CC(=O)OCC(C)(C)C)CCNCC1</smiles>

DO2A-diester

Figure 3. The building blocks for the synthesis of the target compounds.<smiles>O=C(Cl)CCl</smiles>

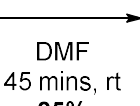
$85 \%$<smiles>O=C(CCl)Oc1ccc(O)cc1</smiles><smiles>CCOc1ccc(OC(=O)CCl)cc1</smiles><smiles>O=C(Cl)CCl</smiles><smiles>O=C(CCl)Oc1ccc(OC(=O)CCl)cc1</smiles>

Scheme 2. Reaction leading to compounds 1, 2 and 3.

Protected ligands 4 and 5 are synthesized by linking the pendant arms 2 and 3, respectively, to the DO3A-triester via nucleophilic substitution. For 4, stirring in $\mathrm{MeCN}$ with $\mathrm{NaHCO}_{3}$ for $26 \mathrm{~h}$ gives the desired compound as a transparent oil in moderate yields (55-60\% over 4 runs of the reaction). Compound 5 is obtained in $52 \%$ yield as a yellow viscous oil in similar conditions under reflux and with DIPEA as base, see Scheme 3.

For the preparation of protected ligand 9, the reported procedure [52], as seen in Scheme 4, first requires the formation of the regioselectively disubstituted cyclen with the carboxylbenzyl group. The synthesis is carried out with benzyl chloroformate at $60{ }^{\circ} \mathrm{C}$ in chloroform for $100 \mathrm{~min}$, giving the disubstituted compound as a colourless oil in $57 \%$ yield after work up. The introduction of tert-butyl acetate groups is conducted in refluxing acetonitrile with DIPEA for $30 \mathrm{~min}$ in excellent yield, giving 7 as a pale yellow oil. The removal of the carboxylbenzyl groups is achieved by microwave irradiation in isopropanol catalyzed by $\mathrm{Pd} / \mathrm{C}$ with ammonium formate as source of hydrogen, yielding compound 8 as a white solid (98\%). The resulting DO2A-diester is reacted with the pendant arm 2 and DIPEA in refluxing acetonitrile for $2 \mathrm{~h}$, giving the protected ligand 9 as a pale yellow oil in reasonable yields after purification by column chromatography ( $50-55 \%$ after 2 runs of the reaction). 


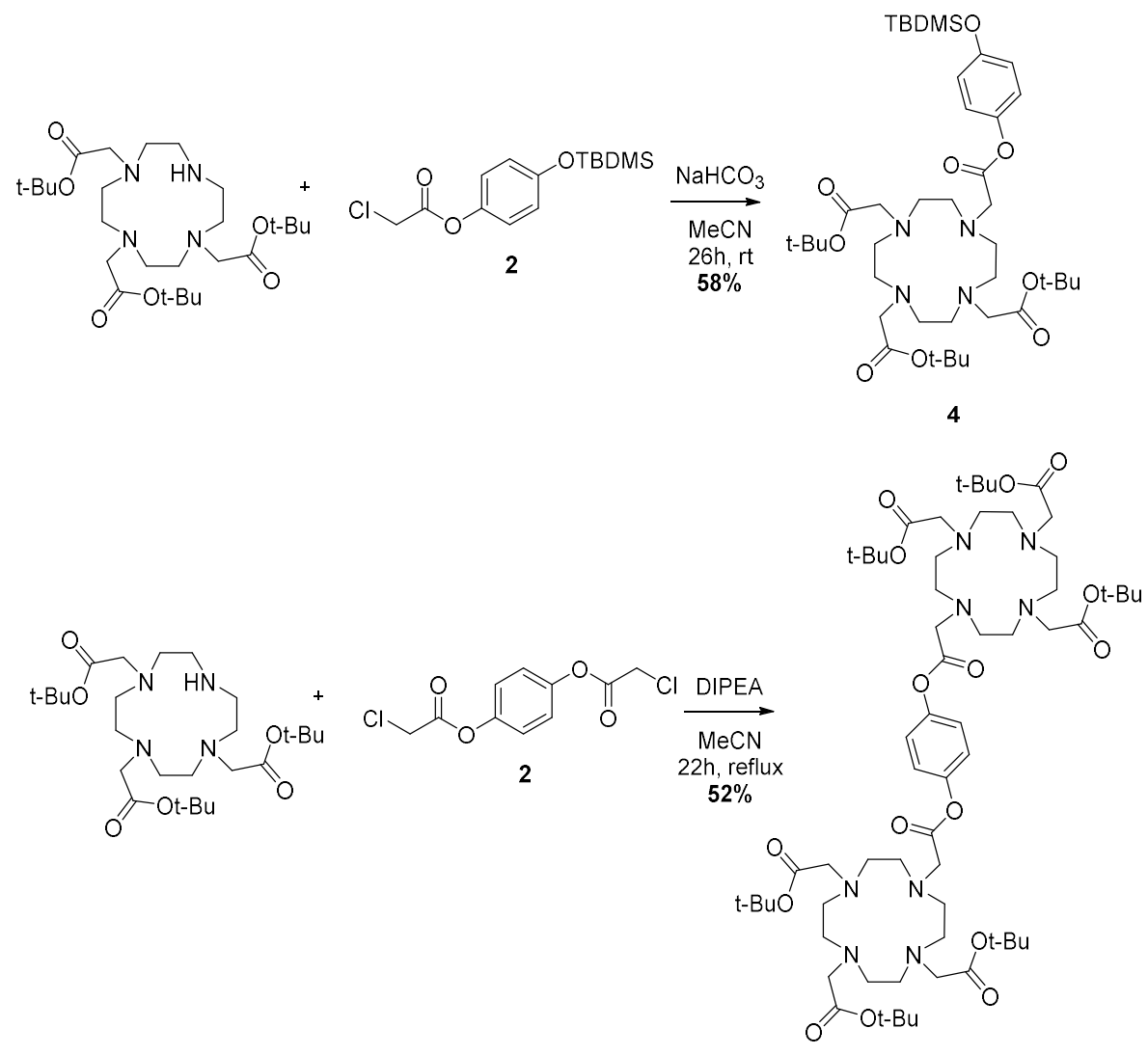

5

Scheme 3. Reaction forming the DOTA-tetraesters 4 and 5.

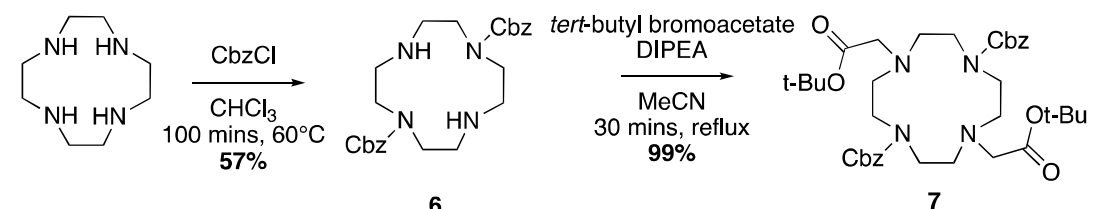<smiles>CCCCOc1ccc(OC(=O)CN2CCN(CC(=O)OCC(C)(C)C)CCN(CC(=O)Oc3ccc(OC(C)(C)C)cc3)CCN(CC(=O)Oc3ccc(OC(C)(C)C)cc3)CC2)cc1</smiles>

Ammonium Formate Ammonium Form iPr, $\mu$ wave 15 mins, reflux $98 \%$

Scheme 4. Reaction series leading to the DOTA-tetraester 9. 
The deprotection of both the tert-butyldimethylsilyl and tert-butyl groups is obtained by stirring the protected ligand with TFA in DCM at room temperature. The desired compound is retrieved after multiple triturations from $\mathrm{MeOH}$ and diethyl ether to remove excess TFA. Scheme 5 shows the reaction for the formation of ligand $\mathbf{L}^{\mathbf{1}}$, obtained as a white solid in $39 \%$ yield. $\mathbf{L}^{\mathbf{2}}$ is attained in the same conditions and in comparable yields to $\mathbf{L}^{\mathbf{1}}$ as an off white solid (32\%). In the case of $\mathbf{L}^{3}, 72 \mathrm{~h}$ are required to get acceptable yields (36\%) and give the desired ligand as an off-white powder.

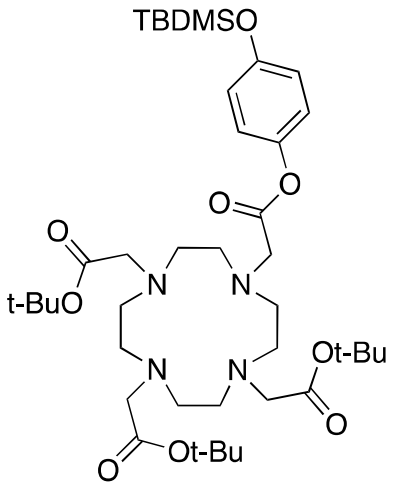

4

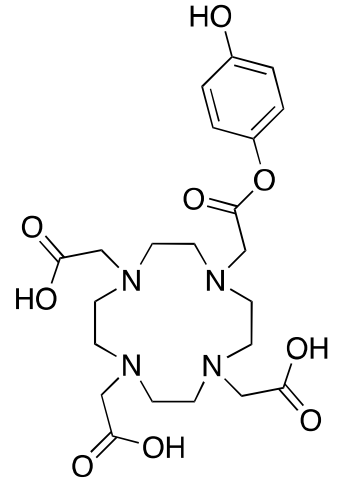

$\mathbf{L}^{1}$

Scheme 5. Deprotection of 4 leading to the DOTA-monoester ligand $\mathbf{L}^{\mathbf{1}}$.

The lanthanide (III) complexes of Eu (III) and Tb (III) with $\mathbf{L}^{\mathbf{1}}, \mathbf{L}^{\mathbf{2}}$ and $\mathbf{L}^{\mathbf{3}}$ are obtained as white powders by reacting the ligand with either 1 equivalent $\left(\mathbf{L}^{1}\right.$ and $\left.\mathbf{L}^{3}\right)$ or 2 equivalents $\left(\mathbf{L}^{2}\right)$ of the lanthanide (III) triflate salt in $\mathrm{MeOH}$ at $60{ }^{\circ} \mathrm{C}$ for $72 \mathrm{~h}$.

\subsection{Characterisation}

The synthesized ligands and complexes were characterized using mass spectrometry and NMR. The ${ }^{1}$ H NMR spectra of the three europium(III) complexes Eu. $\mathbf{L}^{\mathbf{1}}$, Eu. $^{\mathbf{2}}$ and Eu. $\mathbf{L}^{\mathbf{3}}$ are shown in Figure 4 and contrasted to the spectrum of $[\text { Eu.DOTA }]^{-}$. Eu. $\mathbf{L}^{1}$ has no symmetry and resonances from the four axial protons are observed, whereas only a single resonance is seen in the DOTA complex. Eu. $\mathrm{L}^{2}$ and Eu. $\mathrm{L}^{3}$ are both C2 symmetric and a much simpler ${ }^{1} \mathrm{H}$ NMR spectrum is observed. Eu. $\mathrm{L}^{3}$ shows a spectrum very similar to the C4 symmetric DOTA complex. So does Eu. $\mathbf{L}^{2}$, but here the symmetry is broken in a fraction of the population, possibly by association to a capping ligand [53]. Please note that all complexes in Figure 4 are predominately in the SAP conformation.

The ${ }^{1} \mathrm{H}$ NMR spectra indicate a DOTA like structure of all complexes, with added conformational freedom in Eu. $\mathrm{L}^{2}$. This is confirmed by the luminescence emission spectra, where the emission spectrum of Eu. $\mathrm{L}^{2}$ is more similar to that of DO3A than DOTA [53]. In contrast, the emission spectra of Eu. $\mathbf{L}^{\mathbf{1}}$ and Eu. $\mathrm{L}^{\mathbf{3}}$ are both structured, and the band at $590 \mathrm{~nm}$ corresponding to the ${ }^{5} \mathrm{D}_{0} \rightarrow{ }^{7} \mathrm{~F}_{1}$ transition shows the different symmetry of the two complexes. Three lines are resolved for the asymmetric Eu. $\mathbf{L}^{\mathbf{1}}$, and two lines are seen in the symmetric Eu.L ${ }^{3}$. The luminescence spectra are included in Figure 5. Time-gating did not provide any benefits in the model system and only steady-state spectra are used in this study. 


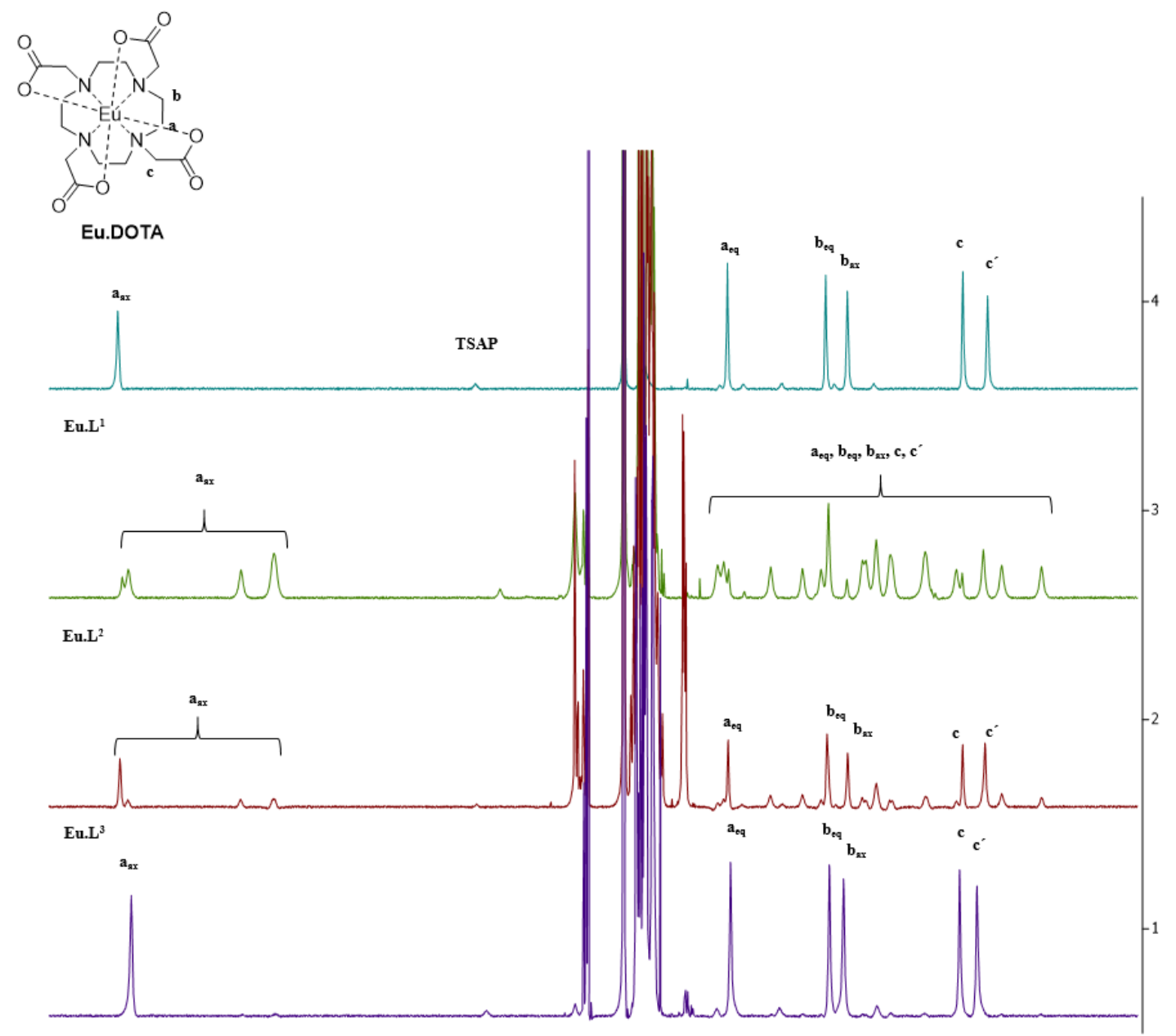

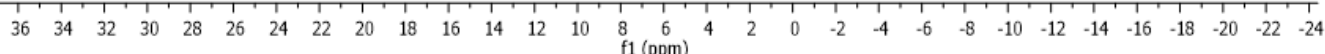

Figure 4. Paramagnetic ${ }^{1} \mathrm{H}$ NMR spectra $\left(500 \mathrm{MHz}, \mathrm{D}_{2} \mathrm{O}\right)$ of Eu.DOTA (top, cyan), Eu.. $\mathbf{L}^{\mathbf{1}}$ (second, green), Eu. $\mathbf{L}^{2}$ (third, red) and Eu. $\mathbf{L}^{2}$ (bottom, purple).

The last panels in Figure 5 show the steady-state and time-gated emission spectrum of Tb. $\mathbf{L}^{\mathbf{1}}$. Excitation in the absorption band of the hydroquinone unit clearly gives rise to terbium(III) centred emission, with appreciable efficiency. Thus, the terbium(III) complexes can be used as intensity-based probes, as oxidation will lead to loss of the hydroquinone unit which is followed by a significant loss of emission intensity. The caveat for using this mode of operation is that it requires excitation in the deep UV. The excitation spectrum in Figure 5b shows that direct excitation of europium(III) is more efficient than the antenna-mediated excitation, and this will not be considered further. All excitation and emission spectra are available as Supplementary Materials.

The luminescent lifetimes of the complexes were determined using an exponential fit to the time-resolved emission decay profiles. The results are compiled in Table 1, and show clear differences between the complexes. In Tb. $\mathbf{L}^{2}$ and $\mathbf{T b} \cdot \mathrm{L}^{3}$ the terbium excited state lifetime is reduced by ligand

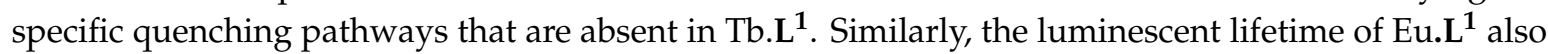
resembles those observed from other DO3A complexes [53], while those observed in Eu. $\mathbf{L}^{2}$ and Eu. $\mathbf{L}^{3}$ are significantly reduced. This suggest additional quenching pathways operate in $\mathbf{L n} . \mathbf{L}^{2}$ and $\mathbf{L n} . \mathbf{L}^{3}$, both redox mediated charge transfer and back energy transfer to the antenna centred triplet state are viable explanations. As the luminescence intensity is important for an efficient molecular probe, 
further developments should exploit the Ln. $\mathbf{L}^{\mathbf{1}}$ scaffold as-based on the luminescence lifetime-this is the most promising candidate of the three.

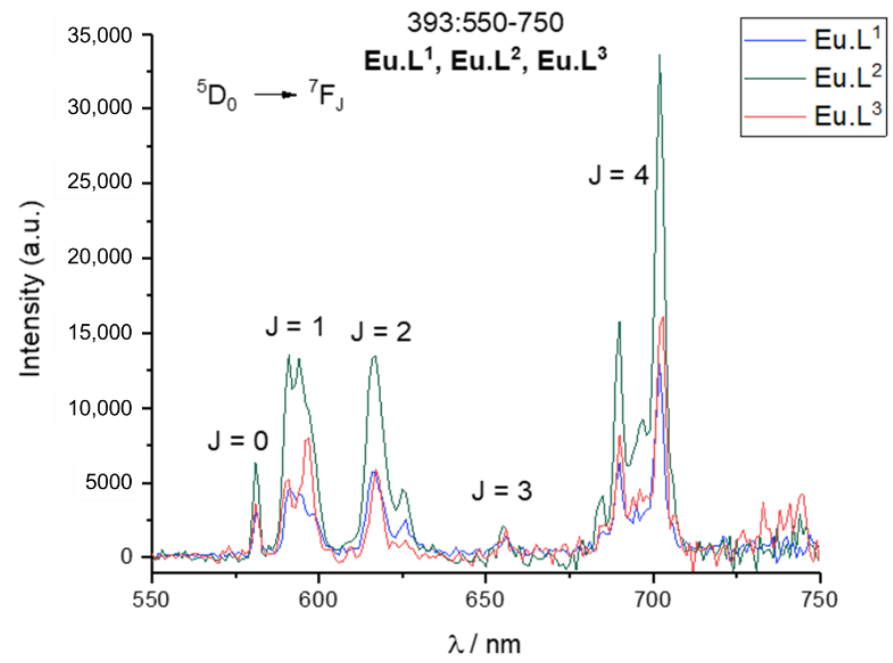

(a)

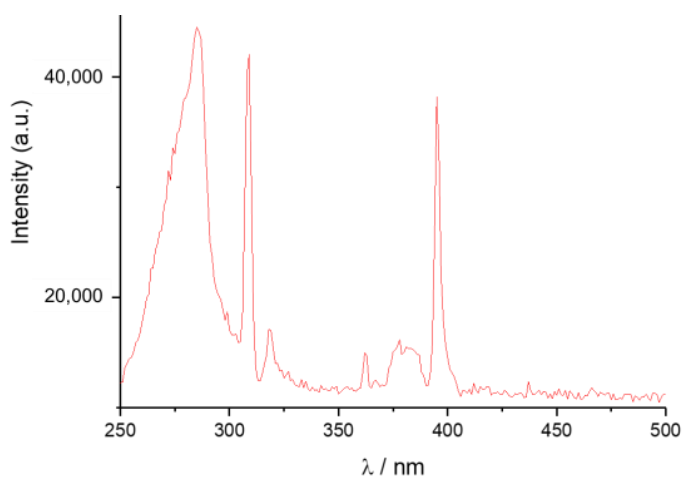

(b)

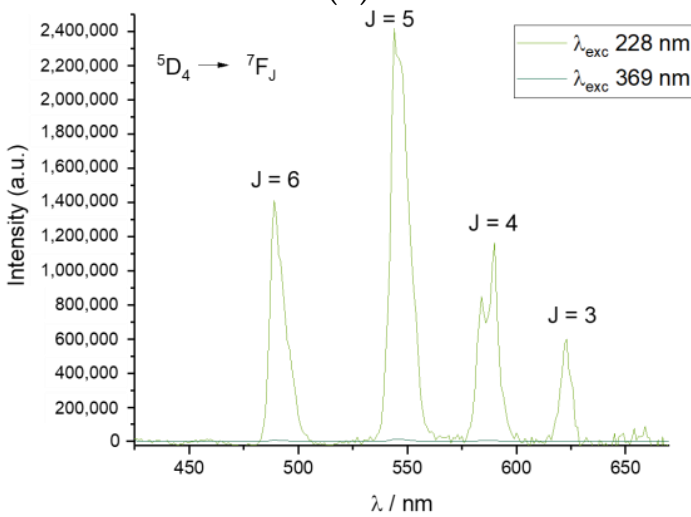

(d)

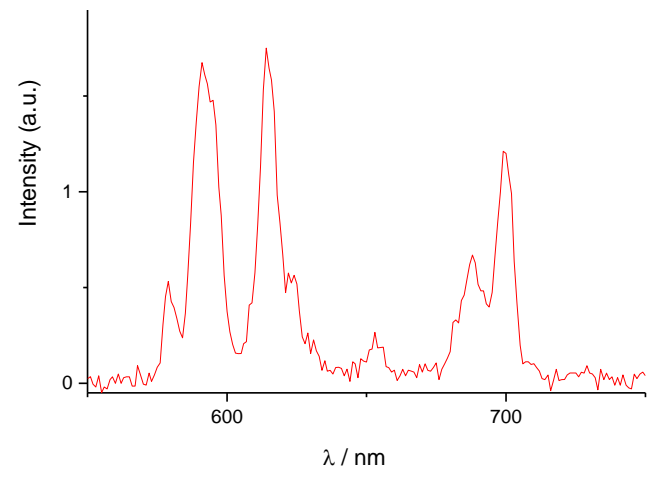

(c)

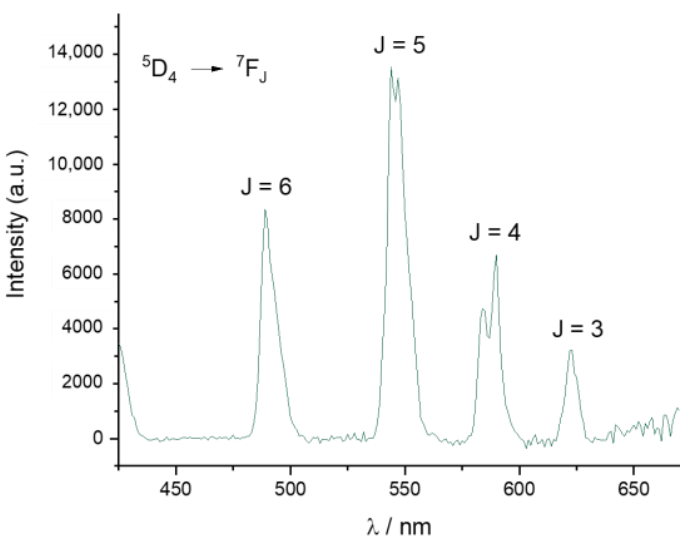

(e)

Figure 5. Steady-state and time-gated luminescence spectra. (a) Emission spectra at $393 \mathrm{~nm}$ excitation of Eu. $\mathbf{L}^{1}$, Eu. $\mathbf{L}^{2}$ and Eu. $\mathbf{L}^{3}$ in HEPES $0.1 \mathrm{mM}$ pH 7.2. (b) Time-gated Eu. $\mathbf{L}^{2}$ excitation with emission at $618 \mathrm{~nm}$ in HEPES $0.1 \mathrm{mM}$ pH 7.2. (c) Time-gated Eu. $\mathrm{L}^{2}$ emission with excitation at $285 \mathrm{~nm}$ in HEPES $0.1 \mathrm{mM}$ pH 7.2. (d) Steady-state Tb. $\mathbf{L}^{\mathbf{1}}$ emission spectra at $228 \mathrm{~nm}$ and $369 \mathrm{~nm}$ excitation in HEPES $0.1 \mathrm{mM}$ pH 7.2. (e) Time-gated Tb.L ${ }^{1}$ emission at $369 \mathrm{~nm}$ excitation in HEPES 0.1 mM pH 7.2. 
Table 1. Luminescent lifetimes (ms) of the europium(III) and terbium(III) complexes determined in the relevant medium and $\mathrm{D}_{2} \mathrm{O}$.

\begin{tabular}{ccc}
\hline Compound & $\mathbf{0 . 1}$ M HEPES $\mathbf{p H} \mathbf{7 . 2}$ & $\mathbf{D}_{\mathbf{2}} \mathbf{O}^{\mathbf{1}}$ \\
\hline Eu. $\mathbf{L}^{\mathbf{1}}$ & 0.524 & 1.391 \\
Eu. $\mathbf{L}^{\mathbf{2}}$ & $0.086(17 \%) / 0.546(83 \%)$ & 0.792 \\
Eu. $\mathbf{L}^{\mathbf{3}}$ & 0.259 & 0.917 \\
\hline Tb. $\mathbf{L}^{\mathbf{1}}$ & 1.273 & 1.931 \\
$\mathrm{~Tb} . \mathbf{L}^{\mathbf{2}}$ & 0.420 & 0.776 \\
$\mathrm{~Tb} . \mathbf{L}^{\mathbf{3}}$ & 0.366 & 0.929 \\
\hline
\end{tabular}

${ }^{1}$ As the conditions are widely different the number of inner sphere solvent molecules (q) [54-56] was not calculated.

\subsection{Response to Reactive Oxygen Species}

The response of Eu. $\mathbf{L}^{1}, \mathrm{Eu} \cdot \mathbf{L}^{2}$, and Eu. $\mathbf{L}^{3}$ towards ROS were studied in detail, and the response of $\mathrm{Tb} . \mathbf{L}^{1}, \mathrm{~Tb} . \mathbf{L}^{2}$, and $\mathrm{Tb} . \mathrm{L}^{3}$ when exposed to hypochlorous acid was investigated. The complexes were dissolved in $0.1 \mathrm{mM}$ HEPES buffer without Triton X-100 as all complexes are fully soluble. $\mathrm{H}_{2} \mathrm{O}_{2}$ or $\mathrm{HClO}$ were added and after $5 \mathrm{~min}$ the spectra were recorded. No reaction was observed with hydrogen peroxide, and we concluded that the complexes are selective for hypochlorous acid.

The response of all six complexes are due to the oxidation of hydroquinone to quinone, and a subsequent hydrolysis of the Ln.DOTA-ester to [Ln.DOTA $]^{-}$. The transformation is shown for Eu. $\mathrm{L}_{1}$ in Scheme 1. For Ln. $\mathbf{L}^{2}$ and Ln. $\mathbf{L}_{3}$ the first oxidation/hydrolysis step leads to the formation of Ln. $\mathbf{L}_{1}$, which then upon a second oxidation is converted to [Ln.DOTA $]^{-}$. Figure 6 shows the spectra of Eu. $\mathbf{L}^{1}$ when 1-25 equivalents of $\mathrm{HOCl}$ have been added. There is a small observable change in intensity, but the most significant change is in the band at $590 \mathrm{~nm}$ arising from the ${ }^{5} \mathrm{D}_{0} \rightarrow{ }^{7} \mathrm{~F}_{1}$ transition. In this band-consisting of three lines-the ligand field can be probed via the three microstates in ${ }^{7} \mathrm{~F}_{1}$. In Eu. $\mathbf{L}^{\mathbf{1}}$, a DO3A system, the three microstates are all resolved, while in the product there are two degenerate microstates. The product spectrum is very similar to that of [Eu.DOTA $]^{-}$, and that the product is indeed [Eu.DOTA] ${ }^{-}$, can be seen from the series of ${ }^{1} \mathrm{H}$ NMR spectra shown in Figure 7. This is further supported by the direct comparison of the Eu. $\mathrm{L}^{1}$ oxidation product luminescence emission spectrum to that of [Eu.DOTA $]^{-}$, see Figure 8a. Thus, the mechanism of the response is confirmed.

The response of the probes can be determined in several ways. Figure 6 shows the ratiometric change in the emission spectrum as the symmetry of the complexes change, which can be converted into a response function by comparing the intensity at two emission wavelengths as done in Figure $8 \mathrm{~b}$. Figure $8 \mathrm{c}$ shows how the intensity of antenna mediated europium(III) luminescence decreases as the caging group is hydrolysed, and Figure $8 \mathrm{~d}$ shows the corresponding response function. Finally, Figure 8e,f shows how the overall intensity increase of the Ln. $\mathbf{L}^{3}$ luminescence can be used as a response. The change in spectral shape can be used for europium(III) only. The intensity response works equally well for europium(III) and terbium(III) complexes.

Figure 8 includes the response function of the three probes as a function of equivalents of $\mathrm{HOCl}$ added. Compared to the response function of the free hydroquinone, a significant excess of oxidant is needed to achieve full conversion of the probes. For all three complexes an excess of 15 equivalents of $\mathrm{HOCl}$ is needed, which indicates that the lanthanide complex significantly reduces the reactivity of the hydroquinone ester. Please note that the mono-esters of hydroquinone in Ln. $\mathbf{L}^{1}$ and $\mathbf{L n} \cdot \mathrm{L}^{3}$ show similar reactivity as the di-ester of hydroquinone in $\mathbf{L n} \cdot \mathrm{L}^{2}$, although full conversion is reached at 30 equivalents for Ln. $\mathrm{L}^{2}$ and 15-25 equivalents with the mono-esters. Furthermore, the two reactions that are required for full conversion of $\mathrm{Ln} . \mathrm{L}^{2}$ and $\mathrm{Ln} . \mathrm{L}^{3}$ are not reflected in the number of equivalents needed for full conversion. Thus, we conclude that the reactivity of the hydroquinone esters is dictated by the structure of the lanthanide complex, rather than the hydroquinone esters themselves. This is supported by the fact that the reaction of the model systems, see Figure 2, proceed with full conversion by addition of the expected two equivalents of hROS. 


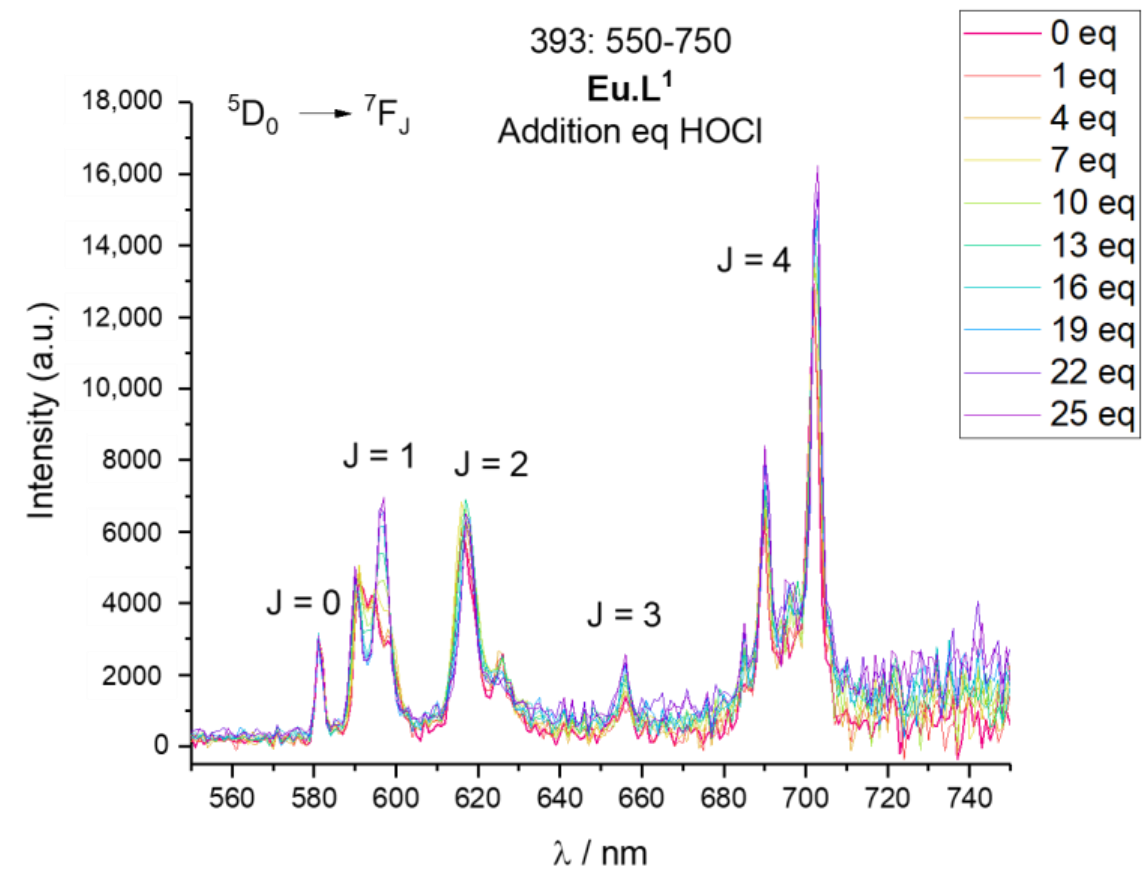

(a)

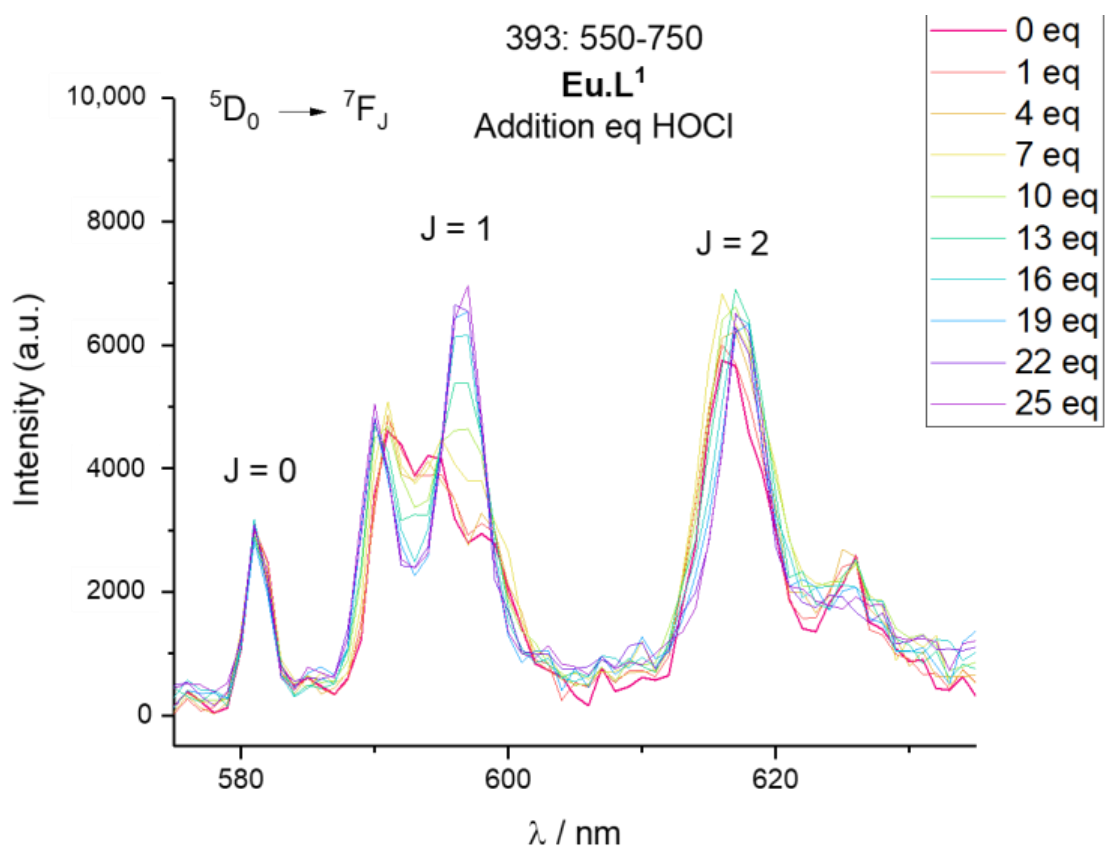

(b)

Figure 6. Luminescence spectra of Eu. $\mathbf{L}^{\mathbf{1}}$ upon oxidation with $\mathrm{HOCl}$. (a) Emission spectra of Eu. $\mathbf{L}^{\mathbf{1}}$ at $393 \mathrm{~nm}$ excitation following the titration of increasing equivalents of $\mathrm{HOCl}$ in $\mathrm{HEPES} 0.1 \mathrm{mM} \mathrm{pH} \mathrm{7.2.}$ (b) Zoomed in section of the emission spectra of Eu. $\mathbf{L}^{\mathbf{1}}$ at $393 \mathrm{~nm}$ excitation following the titration of increasing equivalents of $\mathrm{HOCl}$ in HEPES $0.1 \mathrm{mM}$ pH 7.2. 


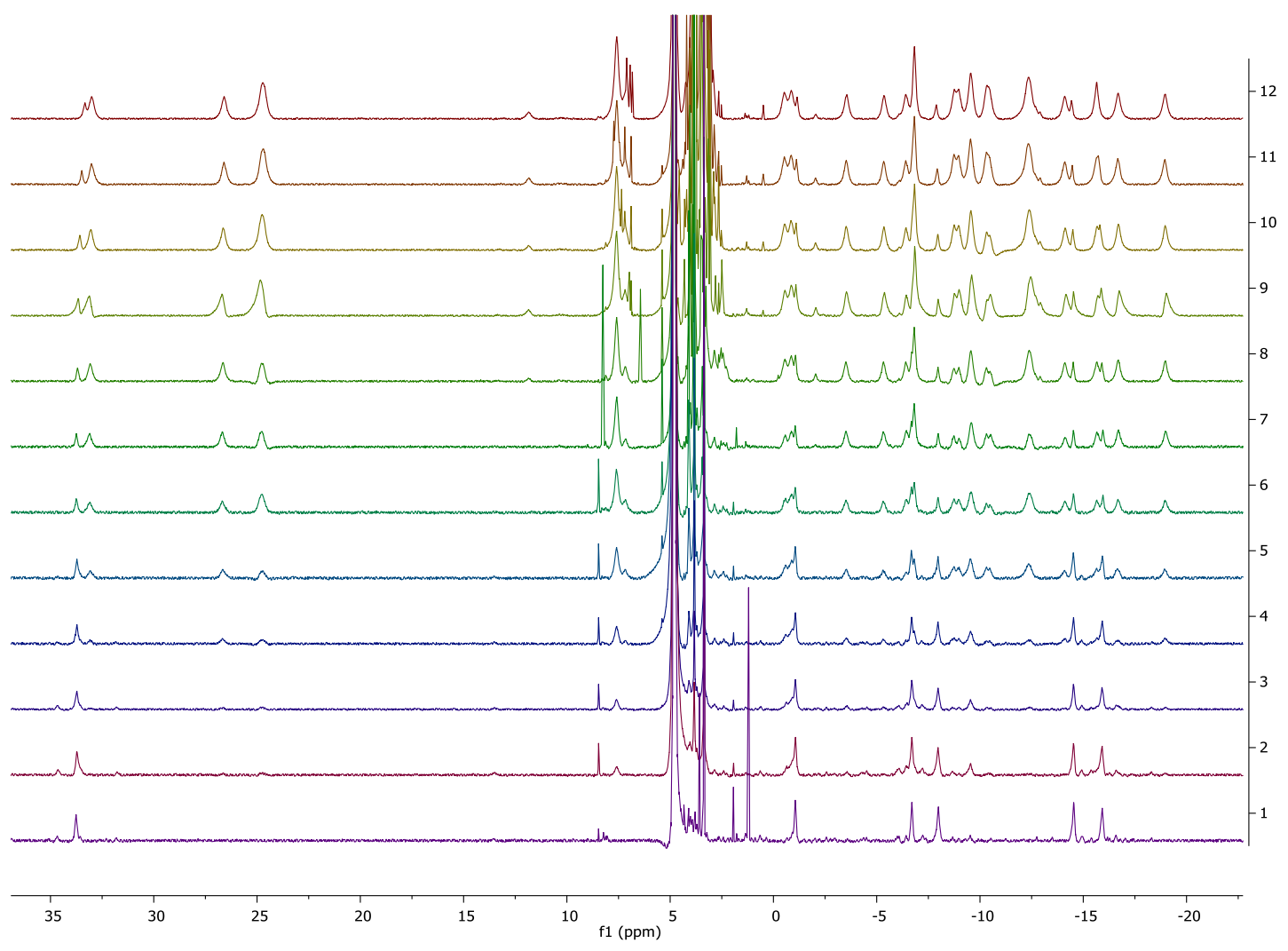

Figure 7. Paramagnetic ${ }^{1} \mathrm{H}-\mathrm{NMR}\left(500 \mathrm{MHz}, \mathrm{D}_{2} \mathrm{O}\right)$ titrations of $\mathrm{HOCl}$ in $\mathrm{Eu}^{\mathrm{L}} \mathrm{L}^{\mathbf{1}}(0,1,2,3,6,9,12,15,18$, 21, 24, 27 equivalents from top to bottom).

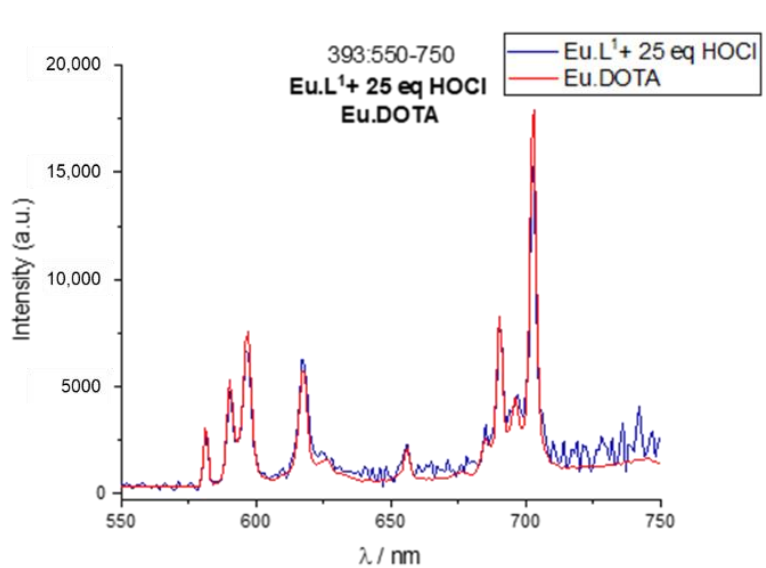

(a)

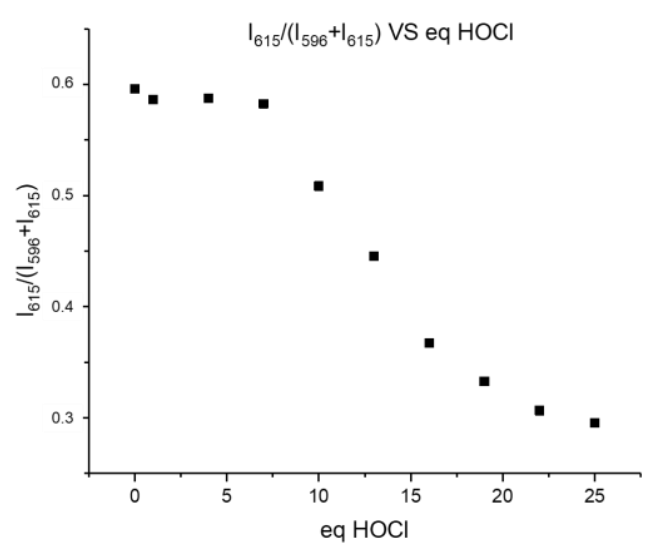

(b)

Figure 8. Cont. 


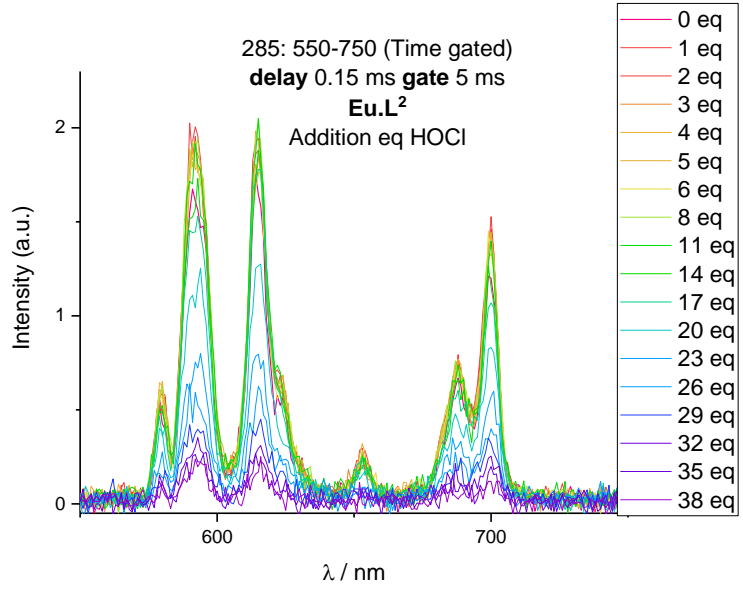

(c)

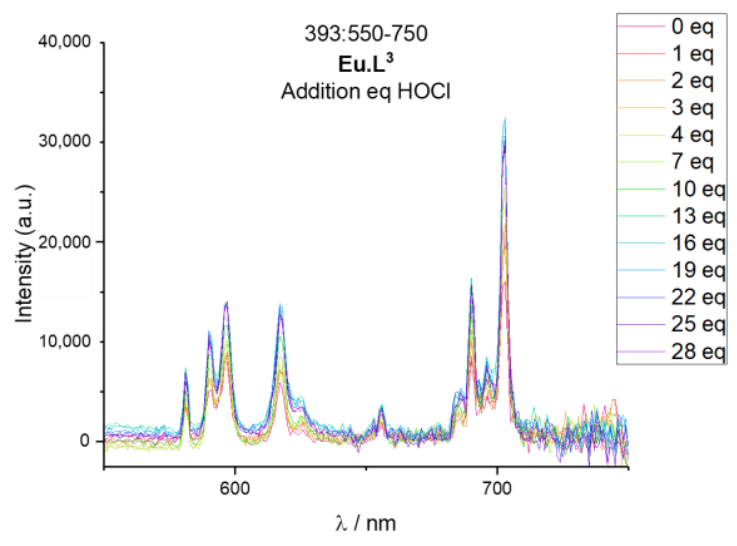

(e)

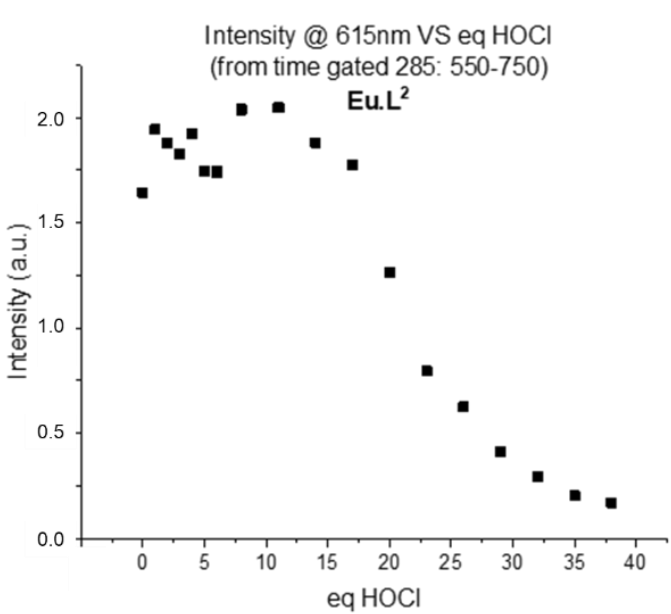

(d)

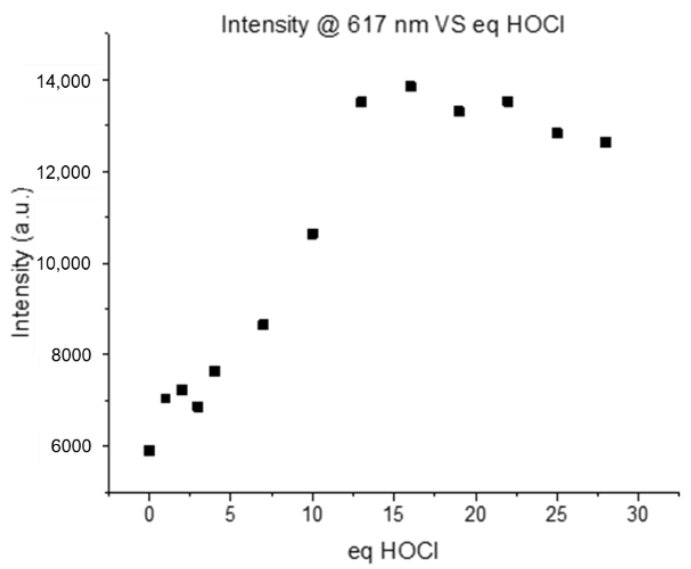

(f)

Figure 8. Oxidation of Eu. $\mathrm{L}^{1}$, Eu. $\mathbf{L}^{2}$, and $\mathrm{Eu} . \mathrm{L}^{3}$ with $\mathrm{HOCl}$ followed using europium(III) luminescence. (a) Emission spectra of Eu.DOTA (red) and Eu.L ${ }^{1}$ (blue) after 25 equivalents of $\mathrm{HOCl}$ at $393 \mathrm{~nm}$ excitation in HEPES $0.1 \mathrm{mM} \mathrm{pH} \mathrm{7.2.} \mathrm{(b)} \mathrm{Plot} \mathrm{of} \mathrm{the} \mathrm{ratio} \mathrm{of} \mathrm{intensities} \mathrm{at} 615 \mathrm{~nm}$ and $596 \mathrm{~nm}$ versus equivalents of $\mathrm{HOCl}$. (c) Time gated emission of Eu. $\mathrm{L}^{2}$ at $285 \mathrm{~nm}$ excitation following the titration of increasing equivalents of $\mathrm{HOCl}$ in HEPES $0.1 \mathrm{mM} \mathrm{pH}$ 7.2. (d) Plot of the time gated emission intensity at $615 \mathrm{~nm}$ of Eu. $\mathrm{L}^{2}$ versus equivalents of $\mathrm{HOCl}$. (e) Emission spectra of Eu. $\mathrm{L}^{3}$ at $393 \mathrm{~nm}$ excitation following the titration of increasing equivalents of $\mathrm{HOCl}$ in HEPES 0.1 $\mathrm{mM} \mathrm{pH} \mathrm{7.2.} \mathrm{(f)} \mathrm{Plot} \mathrm{of} \mathrm{the}$ intensity at $617 \mathrm{~nm}$ for Eu. $\mathrm{L}^{3}$ versus equivalents of $\mathrm{HOCl}$.

Although the reported probes have been tested for $\mathrm{HOCl}$ detection, it is informative to examine its response towards other ROS. Eu. $\mathbf{L}^{1}$ has been studied with $\mathrm{H}_{2} \mathrm{O}_{2}$ and the $\mathrm{H}_{2} \mathrm{O}_{2} /$ Horseradish Peroxidase system in PBS buffer with Triton X-100. The results are reported in Figure 9a,b, respectively. The emission spectra of the complex are unchanged after addition of $\mathrm{H}_{2} \mathrm{O}_{2}$ alone or in combination to Horseradish Peroxidase, thus supporting the aim of developing a selective probe towards a single ROS. 


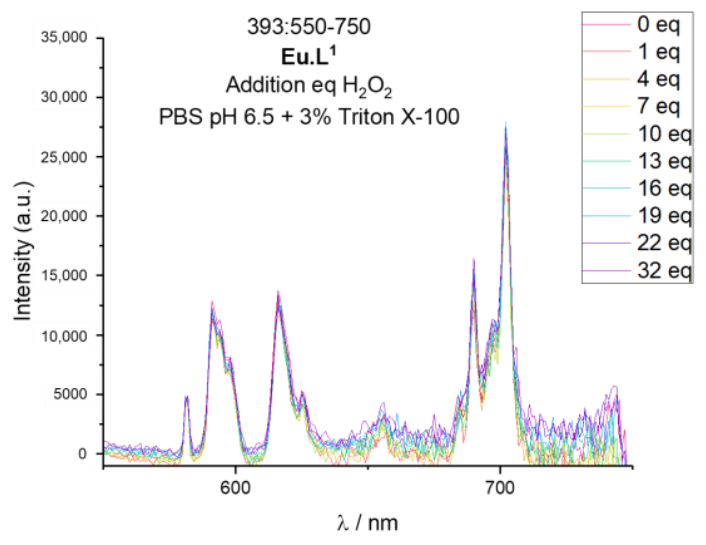

(a)

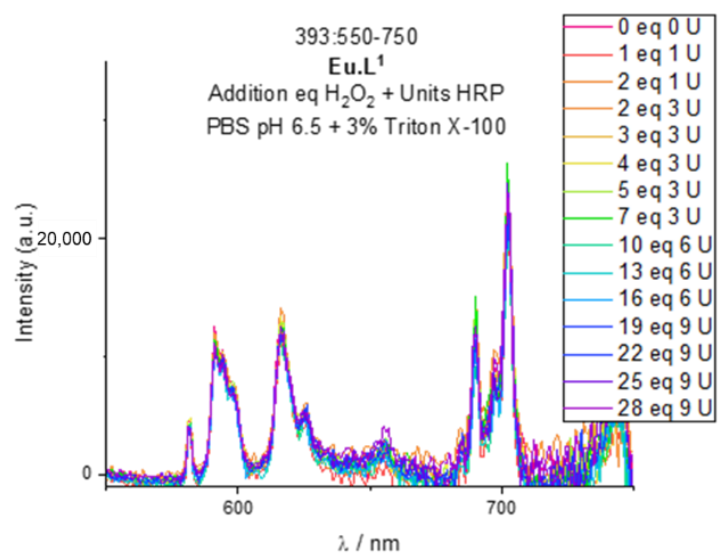

(b)

Figure 9. Testing of Eu. $\mathrm{L}^{1}$ with $\mathrm{H}_{2} \mathrm{O}_{2}$ followed using europium(III) luminescence. (a) Emission spectra of Eu. $\mathrm{L}^{1}$ at $393 \mathrm{~nm}$ excitation following the titration of increasing equivalents of $\mathrm{H}_{2} \mathrm{O}_{2}$ in PBS $0.02 \mathrm{mM}$ at $\mathrm{pH}$ 6.5. (b) Emission spectra of Eu. $\mathrm{L}^{1}$ at $393 \mathrm{~nm}$ excitation following the titration of increasing equivalents of $\mathrm{H}_{2} \mathrm{O}_{2}$ and units of Horseradish Peroxidase in PBS $0.02 \mathrm{mM}$ at $\mathrm{pH} 6.5$.

\section{Materials and Methods}

\subsection{General}

All solvents and chemicals were purchased from Sigma-Aldrich, TCI chemicals, Acros Organics, Alfa Aesar, Fluka, Merck, Abcr or VWR chemicals. The solvents were HPLC or technical grade. Demineralized $\mathrm{H}_{2} \mathrm{O}$ was used. THF was distilled over $\mathrm{Na}$ /benzophenone. DMF, DCM and Toluene were dried over activated molecular sieves (4A). Inert atmosphere for reactions was obtained by either maintaining a constant argon flow from a balloon filled with argon and connected through a syringe needle in a septum or from constant flow of nitrogen through a bubbler. All synthesized compounds containing air-sensitive units were stored under inert gas in small vials for a maximum of 5 weeks and, after that time, their condition was checked before use. Column chromatography was performed

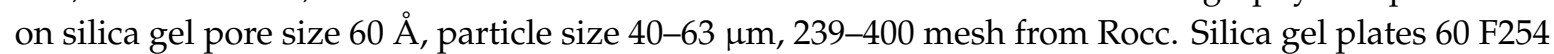
from Merck were used for thin layer chromatography. ${ }^{1} \mathrm{H}-\mathrm{NMR}$ and ${ }^{13} \mathrm{C}-\mathrm{NMR}$ spectra were recorded on a Bruker $500 \mathrm{MHz}$ and $126 \mathrm{MHz}$ respectively. All chemical shifts $(\delta)$ are expressed in parts per million (ppm). The deuterated solvents were used as internal references with the reported values $\left(\mathrm{CDCl}_{3} \delta H 7.26 \delta \mathrm{C} 77.16, \mathrm{CD}_{3} \mathrm{OD} \delta H 3.31 \delta \mathrm{C} 49.00, \mathrm{D}_{2} \mathrm{O} \delta H 4.79\right)$. ESI ${ }^{+}-\mathrm{MS}$ spectra were recorded on a Bruker Solarix FTICR instrument. MALDI-TOF spectra were recorded on a Bruker Speed Autoflex with dithranol as matrix. GC-MS traces and spectra were recorded on an Agilent 6890 Series (GC system) and Agilent 5973 Mass Selective Detector with tert-butylmethyl ether as solvent for injections. Melting points are uncorrected and measured on a Stuart SMP30 instrument. All aqueous solutions were prepared in demineralized water. The $\mathrm{pH}$ for buffer solutions was measured with a Mettler-Toledo Seven Easy pH meter. HEPES buffer $0.1 \mathrm{M}$ was prepared from $2.383 \mathrm{~g}$ of purchased HEPES in $100 \mathrm{~mL}$ of demineralized $\mathrm{H}_{2} \mathrm{O}$. PBS buffer 20 and $40 \mathrm{mM}$ was prepared from diluting purchased PBS buffer $100 \mathrm{mM}$. Aqueous solution of $\mathrm{HOCl} 5 \%$ w/v was prepared from $384 \mathrm{mg}$ of purchased $\mathrm{Ca}(\mathrm{OCl})_{2}(65 \%$ available chlorine) in $5 \mathrm{~mL}$ of demineralized $\mathrm{H}_{2} \mathrm{O}$. Deuterated $\mathrm{DOCl} 5 \% \mathrm{w} / \mathrm{v}$ solution was prepared from $38.4 \mathrm{mg} \mathrm{Ca}(\mathrm{OCl})_{2}, 65 \%$ available chlorine, in $0.5 \mathrm{~mL} \mathrm{D} \mathrm{D}_{2} \mathrm{O} . \mathrm{H}_{2} \mathrm{O}_{2} 30 \% w / v$ was used as purchased. $\mathrm{H}_{2} \mathrm{O}_{2} 3 \% \mathrm{w} / \mathrm{v}$ was prepared from dilution of the purchased $\mathrm{H}_{2} \mathrm{O}_{2} 30 \% \mathrm{w} / \mathrm{v}$. A solution of Horseradish Peroxidase $750 \mathrm{U} / \mathrm{mL}$ was prepared from $1.41 \mathrm{mg}$ of Horseradish Peroxidase (E.C. 1.11.1.7, 150 U/mg) in $0.282 \mathrm{~mL}$ PBS $40 \mathrm{mM}$ at $\mathrm{pH}$ 6.5.

Absorption spectra were recorded on a Cary $300 \mathrm{UV}-\mathrm{Vis}$ Spectrophotometer at room temperature and using pure solvent as baseline. The slits were set at $2 \mathrm{~nm}$, the integration time was $0.1 \mathrm{~s}$ and the step size was $1 \mathrm{~nm}$. Excitation spectra were acquired on a HORIBA PTI QuantaMaster 8075-22 instrument 
with a Steady State Xenon Arc lamp. The excitation slits were set at $2 \mathrm{~nm}$ and the emission slits at $7 \mathrm{~nm}$, the integration time was $0.15 \mathrm{~s}$ and the step $1 \mathrm{~nm}$ for all experiments unless stated otherwise. The spectra were recorded at $25^{\circ} \mathrm{C}$. The excitation and emission wavelengths are reported on the spectra. The uncorrected spectra were used for qualitative individuation of peaks. Emission spectra were acquired on a HORIBA PTI Quanta Master 8075-22 instrument with a Steady State Xenon Arc lamp. The excitation slits were set at $8 \mathrm{~nm}$ and the emission slits at $2 \mathrm{~nm}$, the integration time was $0.1 \mathrm{~s}$ and the step $1 \mathrm{~nm}$ for all experiments unless stated otherwise. The spectra were recorded at $25{ }^{\circ} \mathrm{C}$. The excitation and emission wavelengths are reported on the spectra. The reported spectra were corrected with the correction file provided with the software. Time-gated emission spectra were acquired on a Cary Eclipse fluorescence spectrometer in phosphorescence mode. The delay time was $0.15 \mathrm{~ms}$ with a gate time of $5 \mathrm{~ms}$. The excitation slits were set to $10 \mathrm{~nm}$ and the emission slits to $5 \mathrm{~nm}$ or $2.5 \mathrm{~nm}$. Lifetime measurements were obtained on a HORIBA PTI QuantaMaster 8075-22 instrument with a Flash Xenon lamp. The excitation slits were set at $8 \mathrm{~nm}$ and the emission slits at $8 \mathrm{~nm}$, the start time was $300 \mu \mathrm{s}$ and end time $10,000 \mu \mathrm{s}$. The spectra were recorded at $25^{\circ} \mathrm{C}$. The excitation and emission wavelengths are reported on the spectra. The data was fitted using OriginPro 2017.Starna Scientific $10 \mathrm{~mm}$ quartz cuvettes were employed for all samples at room temperature.

\subsection{Synthetic Procedures}

\subsubsection{Synthesis of 4-Hydroxyphenyl 2-chloroacetate (1)}

Hydroquinone $(1.00 \mathrm{~g}, 9.08 \mathrm{mmol})$ was dissolved in DMF (18.1 mL). Chloroacetyl chloride $(0.866 \mathrm{~mL}, 10.9 \mathrm{mmol})$ was added dropwise under a positive nitrogen atmosphere over $10 \mathrm{~min}$ and the clear solution soon became pale yellow. After $45 \mathrm{~min}$ the reaction was quenched by addition of $20 \mathrm{~mL}$ $\mathrm{H}_{2} \mathrm{O}$ and the white precipitated diester was filtered off. The filtrate was extracted with $\mathrm{Et}_{2} \mathrm{O}(20 \mathrm{~mL} \times 3)$. The combined organic layers were washed with $\mathrm{H}_{2} \mathrm{O}(30 \mathrm{~mL} \times 2)$ and brine, dried over $\mathrm{MgSO}_{4}$ and concentrated in vacuo to yield the crude compound 1 as a white powder. The crude was recrystallized in $\mathrm{H}_{2} \mathrm{O}$ and pure compound 1 was obtained as white crystals $(1.44 \mathrm{~g}, 7.72 \mathrm{mmol}, 85 \%)$. ${ }^{1} \mathrm{H}-\mathrm{NMR}$ $\left(500 \mathrm{MHz} \mathrm{CDCl}_{3}\right): \delta 6.99\left(\mathrm{~d}, \mathrm{H}_{a r}, 2 \mathrm{H}\right), 6.84\left(\mathrm{~d}, \mathrm{H}_{a r}, 2 \mathrm{H}\right), 4.28\left(\mathrm{~s}, \mathrm{Cl}_{-} \mathrm{CH}_{2}-\mathrm{CO}, 2 \mathrm{H}\right){ }^{13} \mathrm{C}-\mathrm{NMR}(300 \mathrm{MHz}$, $\left.\mathrm{CDCl}_{3}\right): \delta 153.75(\mathrm{C} 4) 122.29\left(\mathrm{C}_{\mathrm{ar}}\right), 116.21\left(\mathrm{C}_{\mathrm{ar}}\right), 41.01(\mathrm{Cl}-\mathrm{C}-\mathrm{CO}) \mathrm{ESI}^{+}-\mathrm{MS}_{\mathrm{C}} \mathrm{C}_{8} \mathrm{H}_{7} \mathrm{ClO}_{3}[\mathrm{M}+\mathrm{Na}]^{+} \mathrm{m} / z_{\mathrm{calc}}$ $208.99759 \mathrm{~m} / \mathrm{z}_{\text {found }} 208.99778 \lambda_{\text {abs }}($ HEPES 0.1 M, pH 7.2) $=275 \mathrm{~nm}, 221 \mathrm{~nm}$.

\subsubsection{Synthesis of 4-((Tert-butyldimethylsilyl)oxy)phenyl 2-chloroacetate (2)}

TBDMSCl (400 mg, $2.14 \mathrm{mmol})$ was dissolved in DMF (4.2 mL) and N-Methyl Imidazole (0.64 mL, $8.04 \mathrm{mmol}$ ) was slowly added under a positive nitrogen atmosphere. The mixture was allowed to stir for a few minutes and then a solution of $\mathbf{1}(500 \mathrm{mg}, 2.68 \mathrm{mmol})$ in DMF $(1.9 \mathrm{~mL})$ was introduced. The solution was stirred at room temperature for $4 \mathrm{~h}$ and then quenched by addition of $\mathrm{H}_{2} \mathrm{O}(10 \mathrm{~mL})$. The mixture was extracted with $\mathrm{Et}_{2} \mathrm{O}(15 \mathrm{~mL} \times 3)$ and the combined organic layers were washed with $\mathrm{H}_{2} \mathrm{O}(20 \mathrm{~mL} \times 3)$ and brine. After drying over $\mathrm{MgSO}_{4}$, the solvent was evaporated under reduced pressure to yield a colourless oil. The crude product was purified by column chromatography (8:2 Petroleum Ether: EtOAc) and dried for a day on the oil pump to yield the pure compound 2 as a colourless oil (516 mg, $1.72 \mathrm{mmol}, 64 \%)$. ${ }^{1} \mathrm{H}-\mathrm{NMR}\left(500 \mathrm{MHz}, \mathrm{CDCl}_{3}\right): \delta 6.99\left(\mathrm{~d}, \mathrm{H}_{a r}, 2 \mathrm{H}\right), 6.83(\mathrm{~d}$, $\left.H_{a r}, 2 \mathrm{H}\right), 4.27$ (s, Cl-CH $\left.-\mathrm{CO}, 2 \mathrm{H}\right), 0.98$ (s, Si-C-CH3, $\left.9 H\right), 0.19\left(\mathrm{~s}, \mathrm{Si}-\mathrm{CH}_{3}, 6 \mathrm{H}\right){ }^{13} \mathrm{C}-\mathrm{NMR}(300 \mathrm{MHz}$, $\left.\mathrm{CDCl}_{3}\right): \delta 166.21(\mathrm{CO}), 153.85(\mathrm{C} 4), 121.95\left(\mathrm{C}_{\mathrm{ar}}\right), 120.79\left(\mathrm{C}_{\mathrm{ar}}\right), 41.05(\mathrm{Cl}-\mathrm{C}-\mathrm{CO}), 25.78\left(\mathrm{Si}-\mathrm{C}-\left(\mathrm{CH}_{3}\right)_{3}\right), 18.32$ $\left(\mathrm{Si}-\mathrm{C}-\left(\mathrm{CH}_{3}\right)_{3},-4.32\left(\mathrm{Si}-\mathrm{CH}_{3}\right) \mathrm{ESI}^{+}-\mathrm{MS}: \mathrm{C}_{14} \mathrm{H}_{21} \mathrm{ClO}_{3} \mathrm{Si}[\mathrm{M}+\mathrm{H}]^{+} \mathrm{m} / z_{\text {calc }} 301.10213 \mathrm{~m} / \mathrm{z}_{\text {found }} 301.10223\right.$.

\subsubsection{Synthesis of 1,4-Phenylene bis(2-chloroacetate) (3)}

Hydroquinone $(1.00 \mathrm{~g}, 9.08 \mathrm{mmol})$ and imidazole $(1.36 \mathrm{~g}, 19.98 \mathrm{mmol})$ were dissolved in DMF (18.2 mL). Chloroacetyl chloride $(1.59 \mathrm{~mL}, 19.98 \mathrm{mmol})$ was added dropwise over 5 min under a positive argon atmosphere and the mixture was left stirring overnight at room temperature. The colour of the solution changed from colourless to bright yellow. $\mathrm{H}_{2} \mathrm{O}(25 \mathrm{~mL})$ was added to quench the 
reaction and a part of compound 3 precipitated as a white powder. This was filtered off and repeatedly washed with $\mathrm{H}_{2} \mathrm{O}$. The filtrate was then extracted with $\mathrm{DCM}(15 \mathrm{~mL} \times 3)$, the organic layers were washed with $\mathrm{H}_{2} \mathrm{O}(15 \mathrm{~mL} \times 2)$ and brine. After drying over $\mathrm{MgSO}_{4}$, the solvent was evaporated to yield a white powder. The residue was dissolved in the minimum amount of $\mathrm{EtOH}$ and triturated with $\mathrm{H}_{2} \mathrm{O}$ to yield pure compound $3(2.21 \mathrm{~g}, 8.36 \mathrm{mmol}, 92 \%)$ as ice white flakes. ${ }^{1} \mathrm{H}-\mathrm{NMR}(500 \mathrm{MHz}$, $\left.\mathrm{CDCl}_{3}\right): \delta 7.18\left(\mathrm{~s}, \mathrm{H}_{a r}, 4 \mathrm{H}\right), 4.30\left(\mathrm{~s}, \mathrm{Cl}-\mathrm{CH}_{2}-\mathrm{CO}, 4 \mathrm{H}\right){ }^{13} \mathrm{C}-\mathrm{NMR}\left(300 \mathrm{MHz}, \mathrm{CDCl}_{3}\right): \delta 122.41\left(\mathrm{C}_{\mathrm{ar}}\right), 40.93$ (Cl-C-CO) ESI ${ }^{+}$-MS: $\mathrm{C}_{10} \mathrm{H}_{8} \mathrm{Cl}_{2} \mathrm{O}_{4}[\mathrm{M}+\mathrm{Na}]^{+} \mathrm{m} / \mathrm{z}_{\text {calc }} 284.96919 \mathrm{~m} / \mathrm{z}_{\text {found }} 284.96962$.

3.2.4. Synthesis of Tri-tert-butyl

2,2', 2'-(10-(2-(4-((tert-butyldimethylsilyl)oxy)phenoxy)-2-oxoethyl)-1,4,7,10-tetraazacyclododecane1,4,7-triyl)triacetate (4)

The tert-Butyl triester of DO3A ( $280 \mathrm{mg}, 0.54 \mathrm{mmol})$ was dissolved in $\mathrm{MeCN}(4.5 \mathrm{~mL})$ and $\mathrm{NaHCO}_{3}$ (91 g, $1.09 \mathrm{mmol})$ was added. Compound $2(196 \mathrm{mg}, 0.65 \mathrm{mmol})$ was dissolved in $\mathrm{MeCN}(0.9 \mathrm{~mL})$ and added to the solution.

The reaction was followed with MALDI-TOF (matrix: dithranol) and the mixture was stirred at room temperature for $26 \mathrm{~h}$ under argon. After this time, the solution was diluted with $\mathrm{H}_{2} \mathrm{O}(10 \mathrm{~mL})$ and extracted with DCM $(5 \mathrm{~mL} \times 3)$. The combined organic layers were washed with $\mathrm{H}_{2} \mathrm{O}(5 \mathrm{~mL}$ $\times 3)$ and brine. After drying over $\mathrm{MgSO}_{4}$, the solvent was evaporated and the crude product was purified by column chromatography (9.5-9: $0.5-1 \mathrm{DCM}$ : MeOH) to yield product 4 as a colourless oil. (247 mg, $0.31 \mathrm{mmol}, 58 \%)$. ${ }^{1} \mathrm{H}-\mathrm{NMR}\left(500 \mathrm{MHz}, \mathrm{CDCl}_{3}\right): \delta 6.93\left(\mathrm{~d}, H_{a r}, 2 \mathrm{H}\right), 6.81\left(\mathrm{~d}, H_{a r}, 2 \mathrm{H}\right)$, 4.17-2.62 (m-bs, $\left.\mathrm{H}_{\text {ring }}+\mathrm{N}-\mathrm{CH}_{2}-\mathrm{CO}, 24 \mathrm{H}\right), 1.45(\mathrm{~s}, \mathrm{Ot}-\mathrm{Bu}, 27 \mathrm{H}), 0.98\left(\mathrm{~s}, \mathrm{Si}-\mathrm{C}-\mathrm{CH}_{3}, 9 \mathrm{H}\right), 0.19\left(\mathrm{~s}, \mathrm{Si}-\mathrm{CH}_{3}, 6 \mathrm{H}\right)$ ${ }^{13} \mathrm{C}-\mathrm{NMR}\left(300 \mathrm{MHz}, \mathrm{CDCl}_{3}\right): \delta 122.17\left(\mathrm{C}_{\mathrm{ar}}\right), 120.75\left(\mathrm{C}_{\mathrm{ar}}\right), 56.26,28.24,25.80,-4.31\left(\mathrm{Si}_{-} \mathrm{CH}_{3}\right) \mathrm{ESI}^{+}-\mathrm{MS}$ : $\mathrm{C}_{40} \mathrm{H}_{70} \mathrm{~N}_{4} \mathrm{O}_{9} \mathrm{Si}[\mathrm{M}+\mathrm{H}]^{+} \mathrm{m} / \mathrm{z}_{\text {calc }} 779.49848 \mathrm{~m} / \mathrm{z}_{\text {found }} 779.50212$.

3.2.5. Synthesis of Hexa-tert-butyl 2,2',2'-(10-(1,4-phenylene) bis-1,4,7,10-tetraazacyclododecane-1,4,7-triyl)acetate (5)

The tert-Butyl triester of DO3A (645 mg, $1.25 \mathrm{mmol}$ ) was dissolved in MeCN (4 mL) and DIPEA $(0.43 \mathrm{~mL}, 2.51 \mathrm{mmol})$ was added dropwise. Compound $2(100 \mathrm{mg}, 0.38 \mathrm{mmol})$ was dissolved in $\mathrm{MeCN}$ $(2.5 \mathrm{~mL})$ and added to the solution.

The reaction was followed with MALDI-TOF (matrix: dithranol) and the mixture was refluxed for $22 \mathrm{~h}$ under nitrogen. The solvent was evaporated and the yellow oil was dissolved in DCM and washed with $\mathrm{H}_{2} \mathrm{O}(10 \mathrm{~mL} \times 3)$ and brine.

After drying over $\mathrm{MgSO}_{4}$, the solvent was evaporated to yield crude compound 5 as a yellow plastic. The residue was purified by column chromatography (9.5-9:0.5-1 DCM: MeOH) to yield 5 (242 mg, $0.20 \mathrm{mmol}, 52 \%$ ) as a yellow plastic. ${ }^{1} \mathrm{H}-\mathrm{NMR}\left(500 \mathrm{MHz}, \mathrm{CDCl}_{3}\right): \delta 7.12\left(\mathrm{bs}, \mathrm{H}_{a r}, 4 \mathrm{H}\right), 4.02-2.04$ (bs, $\left.\mathrm{N}-\mathrm{CH}_{2}-\mathrm{CO}+\mathrm{H}_{\text {ring }}, 48 \mathrm{H}\right), 1.50-1.17(\mathrm{bs}, \mathrm{Ot}-\mathrm{Bu}, 54 \mathrm{H}){ }^{13} \mathrm{C}-\mathrm{NMR}\left(300 \mathrm{MHz}, \mathrm{CDCl}_{3}\right): \delta 122.24\left(\mathrm{C}_{\mathrm{ar}}\right)$, $58.81\left(\mathrm{C}_{\text {ring }}\right) 55.04\left(\mathrm{C}_{\text {ring }}\right), 28.23\left(\mathrm{C}_{\mathrm{tBut}}\right), 28.06\left(\mathrm{C}_{\mathrm{tBut}}\right) \mathrm{ESI}^{+}$-MS: $\mathrm{C}_{62} \mathrm{H}_{106} \mathrm{~N}_{8} \mathrm{O}_{16}[\mathrm{M}+\mathrm{H}]^{+} m / z_{\text {calc }} 609.38634$ $\mathrm{m} / \mathrm{z}_{\text {found }} 609.34983$ Melting point: $65.7^{\circ} \mathrm{C}$.

\subsubsection{Synthesis of Dibenzyl 1,4,7,10-tetraazacyclododecane-1,7-dicarboxylate (6)}

Under an inert atmosphere, cyclen $(1 \mathrm{~g}, 5.80 \mathrm{mmol})$ was dissolved in $\mathrm{CHCl}_{3}(52 \mathrm{~mL})$ and $\mathrm{CbzCl}(1.69 \mathrm{~mL}, 11.90 \mathrm{mmol})$ was added dropwise, resulting in the formation of a white precipitate. The mixture was heated to $60^{\circ} \mathrm{C}$ and stirred for $1 \mathrm{~h}$ and $40 \mathrm{~min}$. The $\mathrm{pH}$ at the end of the reaction was confirmed to be acidic. The solvent was evaporated under reduced pressure to yield a white solid mixed with a yellow solid. The solid was washed over a filter with $\mathrm{Et}_{2} \mathrm{O}$ and the residue was taken up with $4 \mathrm{M}$ aq. $\mathrm{NaOH}$ and extracted 4 times with $\mathrm{Et}_{2} \mathrm{O}$. The organic layers were washed with $1 \mathrm{M}$ aq. $\mathrm{NaOH}(\times 2)$ and then dried over $\mathrm{Na}_{2} \mathrm{SO}_{4}$. The solvent was evaporated under reduced pressure to yield compound $6(1.47 \mathrm{~g}, 3.33 \mathrm{mmol}, 57 \%)$ as a colourless oil. ${ }^{1} \mathrm{H}-\mathrm{NMR}\left(500 \mathrm{MHz}, \mathrm{CDCl}_{3}\right): \delta 7.36-7.28(\mathrm{~m}$, $\left.H_{\text {ar }}, 10 \mathrm{H}\right), 5.15$ (s, O-CH $\left.-\mathrm{bz}\right), 3.51-3.35\left(\mathrm{~m}, \mathrm{H}_{\text {ring }}, 8 \mathrm{H}\right), 2.99-2.70\left(\mathrm{~m}, \mathrm{H}_{\text {ring }}, 8 \mathrm{H}\right){ }^{13} \mathrm{C}-\mathrm{NMR}(300 \mathrm{MHz}$, $\left.\mathrm{CDCl}_{3}\right): \delta 128.77\left(\mathrm{C}_{\mathrm{ar}}\right), 128.37\left(\mathrm{C}_{\mathrm{ar}}\right), 128.12\left(\mathrm{C}_{\mathrm{ar}}\right), 67.63(\mathrm{O}-\mathrm{C}-\mathrm{bz}), 51.07\left(\mathrm{C}_{\text {ring }}\right), 50.66\left(\mathrm{C}_{\text {ring }}\right), 50.09\left(\mathrm{C}_{\text {ring }}\right)$, 
$49.52\left(\mathrm{C}_{\text {ring }}\right), 48.89$ ( $\left.\mathrm{C}_{\text {ring }}\right), 48.60$ ( $\mathrm{C}_{\text {ring }}$ ) ESI ${ }^{+}-\mathrm{MS}: \mathrm{C}_{38} \mathrm{H}_{58} \mathrm{~N}_{8} \mathrm{O}_{16}[\mathrm{M}+\mathrm{H}]^{+} \mathrm{m} / \mathrm{z}_{\text {calc }} 441.24963 \mathrm{~m} / \mathrm{z}_{\text {found }}$ 441.25100 .

3.2.7. Synthesis of Dibenzyl

4,10-bis(2-(tert-Butoxy)-2-Oxoethyl)-1,4,7,10-tetraazacyclododecane-1,7-dicarboxylate (7)

Compound 6 (1.47 g, $3.33 \mathrm{mmol})$ was dissolved in MeCN (24 mL). DIPEA (11.59 mL, $66.55 \mathrm{mmol})$ and tert-butyl bromoacetate $(0.98 \mathrm{~mL}, 6.66 \mathrm{mmol})$ was added. The reaction mixture was refluxed for $30 \mathrm{~min}$. The solvent was evaporated to yield an oil and solid mixture. The oil was taken up with $\mathrm{Et}_{2} \mathrm{O}$ and washed with $\mathrm{H}_{2} \mathrm{O}$. After drying over $\mathrm{Na}_{2} \mathrm{SO}_{4}$, the solvent was evaporated under reduced pressure to yield a light yellow oil as pure compound $7(2.21 \mathrm{~g}, 3.30 \mathrm{mmol}, 99 \%) .{ }^{1} \mathrm{H}-\mathrm{NMR}\left(500 \mathrm{MHz}, \mathrm{CDCl}_{3}\right)$ :

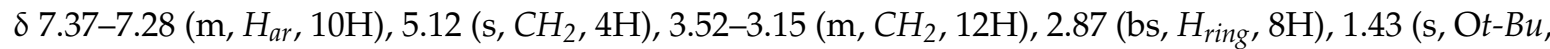
$18 \mathrm{H}){ }^{13} \mathrm{C}-\mathrm{NMR}\left(300 \mathrm{MHz}, \mathrm{CDCl}_{3}\right): \delta 170.70,156.62,137.02\left(\mathrm{C}_{\mathrm{ar}}\right), 128.62\left(\mathrm{C}_{\mathrm{ar}}\right), 128.03\left(\mathrm{C}_{\mathrm{ar}}\right), 81.11,67.14$ (O-C-bz), $56.14\left(\mathrm{CH}_{2}\right), 54.18\left(\mathrm{CH}_{2}\right), 46.72\left(\mathrm{C}_{\text {ring }}\right), 28.35\left(\mathrm{C}_{\mathrm{tBut}}\right) \mathrm{ESI}^{+}$-MS: $\mathrm{C}_{38} \mathrm{H}_{58} \mathrm{~N}_{8} \mathrm{O}_{16}[\mathrm{M}+\mathrm{H}]^{+} \mathrm{m} / z_{\text {calc }}$ $669.38579 \mathrm{~m} / \mathrm{z}_{\text {found }} 669.38769$.

\subsubsection{Synthesis of Di-tert-butyl 2,2'-(1,4,7,10-tetraazacyclododecane-1,7-diyl)diacetate (8)}

To a suspension of $\mathrm{Pd} / \mathrm{C} 10 \%$ (442 $\mathrm{mg}, 20 \% \mathrm{wt}$ ) in iso-propanol $(50 \mathrm{~mL})$, a solution of compound 7 $(2.21 \mathrm{~g}, 3.30 \mathrm{mmol})$ in iso-propanol $(30 \mathrm{~mL})$ was added. Ammonium formate $(9.57 \mathrm{~g}, 152 \mathrm{mmol})$ was added and the mixture was refluxed for 15 min under constant $\mu$ wave irradiation $(150 \mathrm{~W})$. The catalyst was filtered off through celite. The solvent was evaporated and the white solid residue was taken up in $4 \mathrm{M}$ aq. $\mathrm{NaOH}(50 \mathrm{~mL})$ and extracted with $\mathrm{CHCl}_{3}(100 \mathrm{~mL} \times 4)$. The combined organic layers were dried over $\mathrm{Na}_{2} \mathrm{SO}_{4}$ and the solvent evaporated to yield $8(1.30 \mathrm{~g}, 98 \%)$ as a yellow viscous oil that became a white solid after a few days' exposure to air. ${ }^{1} \mathrm{H}-\mathrm{NMR}\left(500 \mathrm{MHz}, \mathrm{CDCl}_{3}\right): \delta 3.31$ (s, $\left.\mathrm{OCCH}_{2}, 4 \mathrm{H}\right), 2.80\left(\mathrm{bs}, H_{\text {ring }}, 8 \mathrm{H}\right), 2.61\left(\mathrm{t}, \mathrm{H}_{\text {ring }}, 8 \mathrm{H}\right), 1.46(\mathrm{~s}, \mathrm{Ot}-\mathrm{Bu}, 18 \mathrm{H}){ }^{13} \mathrm{C}-\mathrm{NMR}\left(300 \mathrm{MHz}, \mathrm{CDCl}_{3}\right)$ : $\delta$ 171.10, 81.15, $57.35\left(\mathrm{CH}_{2}\right), 52.18\left(\mathrm{CH}_{2}\right), 45.87\left(\mathrm{C}_{\text {ring }}\right), 28.36\left(\mathrm{C}_{\text {tBut }}\right)$ ESI ${ }^{+}-\mathrm{MS}: \mathrm{C}_{20} \mathrm{H}_{40} \mathrm{~N}_{4} \mathrm{O}_{4}[\mathrm{M}+\mathrm{H}]^{+}$ $\mathrm{m} / \mathrm{z}_{\text {calc }} 401.31223 \mathrm{~m} / \mathrm{z}_{\text {found }} 401.31280$.

3.2.9. Synthesis of Di-tert-butyl

2,2'-(4,10-bis(2-(4-((tert-butyldimethylsilyl)oxy)phenoxy)-2-oxoethyl)-1,4,7,10-tetraazacyclododecane1,7-diyl)diacetate (9)

Compound 8 ( $350 \mathrm{mg}, 0.87 \mathrm{mmol}$ ) was dissolved in MeCN (4 mL) and DIPEA ( $1.52 \mathrm{~mL}, 8.74 \mathrm{mmol}$ ) was slowly added under a nitrogen atmosphere. After a few minutes, a solution of compound $2(550 \mathrm{mg}$, $1.83 \mathrm{mmol}$ ) in $\mathrm{MeCN}(2.2 \mathrm{~mL}$ ) was added and the mixture was refluxed for $2 \mathrm{~h}$. After this time, the dark brown mixture was concentrated and the resulting brown oil was dissolved in EtOAc and washed three times with $\mathrm{H}_{2} \mathrm{O}$. After drying over $\mathrm{Na}_{2} \mathrm{SO}_{4}$, the solvent was removed under reduced pressure to yield a brown oil. The residue was purified by column chromatography $(9.25: 0.75 \mathrm{DCM} / \mathrm{MeOH})$ to yield compound 9 as a pale yellow oil $(451 \mathrm{mg}, 0.48 \mathrm{mmol}, 55 \%) .{ }^{1} \mathrm{H}-\mathrm{NMR}\left(500 \mathrm{MHz}, \mathrm{CDCl}_{3}\right)$ : $\delta$ $6.96\left(\mathrm{~d}, H_{a r}, 4 \mathrm{H}\right), 6.75\left(\mathrm{~d}, H_{a r}, 4 \mathrm{H}\right), 3.71-2.17$ (m-bs, $\left.H_{\text {ring }}+\mathrm{N}-\mathrm{CH}_{2}-\mathrm{CO}, 24 \mathrm{H}\right), 1.25(\mathrm{~s}, \mathrm{Ot}-\mathrm{Bu}, 18 \mathrm{H}), 0.98$ (s, Si-C-CH $3,18 \mathrm{H}), 0.19\left(\mathrm{~s}, \mathrm{Si}-\mathrm{CH}_{3}, 12 \mathrm{H}\right){ }^{13} \mathrm{C}-\mathrm{NMR}\left(300 \mathrm{MHz}, \mathrm{CDCl}_{3}\right): \delta 173.74,173.01,153.50,144.44$, $122.13\left(\mathrm{C}_{\mathrm{ar}}\right), 120.38\left(\mathrm{C}_{\mathrm{ar}}\right), 82.27,55.86,55.11,27.83,25.78,-4.34\left(\mathrm{Si}-\mathrm{CH}_{3}\right)$ ESI ${ }^{+}-\mathrm{MS} \mathrm{C}_{48} \mathrm{H}_{80} \mathrm{~N}_{4} \mathrm{O}_{10} \mathrm{Si}_{2}$ $[\mathrm{M}+\mathrm{H}]^{+} \mathrm{m} / \mathrm{z}_{\text {calc }} 929.54857 \mathrm{~m} / \mathrm{z}_{\text {found }} 929.55713$.

3.2.10. Synthesis of

2,2', ,'"'-(10-(2-(4-Hydroxyphenoxy)-2-oxoethyl)-1,4,7,10-tetraazacyclododecane-1,4,7-Triyl)triacetic acid $\left(\mathbf{L}^{1}\right)$

Compound 4 (100 mg, $0.13 \mathrm{mmol})$ was dissolved in DCM $(0.32 \mathrm{~mL})$ and TFA $(0.22 \mathrm{~mL}, 3.47 \mathrm{mmol})$ was slowly added to the mixture. The reaction was followed with MALDI-TOF (matrix: dithranol) until the starting material could no longer be observed. The clear solution was stirred at room temperature for 2 days, after which it was concentrated under reduced pressure. The resulting brown oil was dissolved in the minimum amount of $\mathrm{MeOH}$ and triturated multiple times with $\mathrm{Et}_{2} \mathrm{O}$ to yield 
compound $\mathbf{L}^{1}$ ( $\left.25 \mathrm{mg}, 0.12 \mathrm{mmol}, 39 \%\right)$ as a white powder. ${ }^{1} \mathrm{H}-\mathrm{NMR}(500 \mathrm{MHz}, \mathrm{MeOD}): \delta 7.02\left(\mathrm{~d}, \mathrm{H}_{\text {ar }}\right.$, $2 \mathrm{H}), 6.77\left(\mathrm{~d}, \mathrm{H}_{a r}, 2 \mathrm{H}\right), 4.01\left(\mathrm{~s}, \mathrm{~N}-\mathrm{CH}_{2}-\mathrm{CO}, 2 \mathrm{H}\right), 3.81\left(\mathrm{~s}, \mathrm{~N}-\mathrm{CH}_{2}-\mathrm{CO}, 4 \mathrm{H}\right), 3.62-2.47\left(\mathrm{~m}, \mathrm{~N}-\mathrm{CH}_{2}-\mathrm{CO}+\mathrm{H}_{\text {ring }}\right.$, 8H), 3.19-3.11 (m, $\left.H_{\text {ring }}, 8 \mathrm{H}\right){ }^{13} \mathrm{C}-\mathrm{NMR}(300 \mathrm{MHz}, \mathrm{MeOD}): \delta 144.47(\mathrm{C} 4), 123.43\left(\mathrm{C}_{\mathrm{ar}}\right), 116.52\left(\mathrm{C}_{\mathrm{ar}}\right)$, 57.58, 54.27, $52.51 \mathrm{ESI}^{+}-\mathrm{MS}: \mathrm{C}_{22} \mathrm{H}_{32} \mathrm{~N}_{4} \mathrm{O}_{9}[\mathrm{M}+\mathrm{H}]^{+} \mathrm{m} / \mathrm{z}_{\text {calc }} 497.22421 \mathrm{~m} / \mathrm{z}_{\text {found }} 497.22337$ Melting point: $175.2^{\circ} \mathrm{C}$.

\subsubsection{Synthesis of 10-(1,4-Phenylene) bis-1,4,7,10-tetraazacyclododecane-1,4,7-Triyl)acetate $\left(\mathbf{L}^{2}\right)$}

Compound 5 ( $200 \mathrm{mg}, 0.16 \mathrm{mmol})$ was dissolved in DCM $(0.3 \mathrm{~mL})$ and TFA $(0.37 \mathrm{~mL}, 5.74 \mathrm{mmol})$ was added dropwise. The clear solution was stirred at room temperature for two days. After this time the solvent was evaporated and the resulting brown oil was dissolved in the minimum amount of $\mathrm{MeOH}$ and triturated with $\mathrm{Et}_{2} \mathrm{O}$ to yield compound $\mathrm{L}^{2}(47 \mathrm{mg}, 0.05 \mathrm{mmol}, 32 \%)$ as a white powder. ${ }^{1} \mathrm{H}-\mathrm{NMR}\left(500 \mathrm{MHz}, \mathrm{D}_{2} \mathrm{O}\right): 87.28-6.93\left(\mathrm{~m}, \mathrm{H}_{\text {ar }}, 4 \mathrm{H}\right), 4.04-3.08\left(\mathrm{~m}, \mathrm{~N}-\mathrm{CH}_{2}-\mathrm{CO}+\mathrm{H}_{\text {ring }}, 48 \mathrm{H}\right){ }^{13} \mathrm{C}-\mathrm{NMR}$ (300 MHz, $\left.\mathrm{D}_{2} \mathrm{O}\right): \delta 122.67\left(\mathrm{C}_{\text {ar }}\right), 51.37$ ( $\left.\mathrm{C}_{\text {ring }}\right), 48.01\left(\mathrm{C}_{\text {ring }}\right) \mathrm{ESI}^{+}-\mathrm{MS}: \mathrm{C}_{38} \mathrm{H}_{58} \mathrm{~N}_{8} \mathrm{O}_{16}[\mathrm{M}+\mathrm{H}]^{+} \mathrm{m} / z_{\text {calc }}$ $442.20581 \mathrm{~m} / \mathrm{z}_{\text {found }} 442.20612$ Melting point: $216.7^{\circ} \mathrm{C}$.

3.2.12. Synthesis of

2,2'-(4,10-Bis(2-(4-hydroxyphenoxy)-2-oxoethyl)-1,4,7,10-tetraazacyclododecane-1,7-diyl)diacetic Acid $\left(\mathbf{L}^{3}\right)$

Compound 9 ( $326 \mathrm{mg}, 0.35 \mathrm{mmol})$ was dissolved in DCM $(0.17 \mathrm{~mL})$ and TFA $(0.80 \mathrm{~mL}, 12.28 \mathrm{mmol})$ was slowly added to the mixture. The clear solution was stirred at room temperature for 3 days. After this time, it was concentrated under reduced pressure. The brown oil was dissolved in a minimum amount of $\mathrm{MeOH}$ and triturated multiple times with $\mathrm{Et}_{2} \mathrm{O}$ to yield compound $\mathrm{L}^{3}$ (75 mg, $0.13 \mathrm{mmol}$, $36 \%)$ as an off-white powder. ${ }^{1} \mathrm{H}-\mathrm{NMR}\left(500 \mathrm{MHz}, \mathrm{D}_{2} \mathrm{O}\right): \delta 7.00\left(\mathrm{~d}, \mathrm{H}_{a r}, 4 \mathrm{H}\right), 6.87\left(\mathrm{~d}, H_{a r}, 4 \mathrm{H}\right), 3.96(\mathrm{~s}$, $\left.\mathrm{N}-\mathrm{CH}_{2}-\mathrm{CO}, 4 \mathrm{H}\right), 3.91\left(\mathrm{~s}, \mathrm{~N}-\mathrm{CH}_{2}-\mathrm{CO}, 4 \mathrm{H}\right), 3.60$ (s, $\left.\mathrm{H}_{\text {ring }}, 4 \mathrm{H}\right), 3.53\left(\mathrm{~s}, \mathrm{H}_{\text {ring }}, 4 \mathrm{H}\right), 3.20$ (s, $\left.\mathrm{H}_{\text {ring }}, 4 \mathrm{H}\right), 3.15$ $\left(\mathrm{s}, \mathrm{H}_{\text {ring }}, 4 \mathrm{H}\right){ }^{13} \mathrm{C}-\mathrm{NMR}\left(300 \mathrm{MHz}, \mathrm{D}_{2} \mathrm{O}\right): \delta 122.56\left(\mathrm{C}_{\mathrm{ar}}\right), 116.01\left(\mathrm{C}_{\mathrm{ar}}\right), 51.36,47.91 \mathrm{ESI}^{+}-\mathrm{MS} \mathrm{C}_{22} \mathrm{H}_{32} \mathrm{~N}_{4} \mathrm{O}_{9}$ $[\mathrm{M}+\mathrm{H}]^{+} \mathrm{m} / \mathrm{z}_{\text {calc }} 589.25042 \mathrm{~m} / \mathrm{z}_{\text {found }} 589.24967$ Melting point: $214.1^{\circ} \mathrm{C}$.

\subsection{Synthesis of the Complexes}

The ligand $\mathrm{L}^{\mathrm{n}}(1 \mathrm{eq})$ was dissolved in $\mathrm{MeOH}$ and $\mathrm{Ln}(\mathrm{OTf})_{3}(\mathbf{1}$ eq for $n=1,3 ; \mathbf{2}$ eq for $n=2)$ was added to the solution. The reaction mixture was stirred at $60^{\circ} \mathrm{C}$ for $48-72 \mathrm{~h}$. After this time, the solvent was evaporated and the residue was dissolved in a minimal amount of $\mathrm{MeOH}$ and precipitated with diethyl ether to yield a white powder. The complexes were dried by the freeze-dry method, stored in sealed vials under argon and dried again at the oil pump before every use.

\subsubsection{Eu. $\mathbf{L}^{1}$}

${ }^{1} \mathrm{H}-\mathrm{NMR}\left(500 \mathrm{MHz}, \mathrm{D}_{2} \mathrm{O}\right): \delta 33.37\left(\mathrm{~s}, \mathrm{H}_{\mathrm{a}-\mathrm{ax}}\right), 32.99\left(\mathrm{~s}, \mathrm{H}_{\mathrm{a}-\mathrm{ax}}\right), 26.63\left(\mathrm{~s}, \mathrm{H}_{\mathrm{a}-\mathrm{ax}}\right), 24.73\left(\mathrm{~s}, \mathrm{H}_{\mathrm{a}-\mathrm{ax}}\right), 11.84$ (s, $\left.\mathrm{H}_{\mathrm{a}-\mathrm{ax}}\right), 7.58(\mathrm{~s}),-0.50(\mathrm{~s}),-0.83(\mathrm{~s}),-1.17(\mathrm{~s}),-3.54(\mathrm{~s}),-5.40(\mathrm{~s}),-6.45(\mathrm{~s}),-6.85(\mathrm{~s}),-7.92(\mathrm{~s}),-8.97$ $(\mathrm{s}),-9.57(\mathrm{~s}),-10.48(\mathrm{~s}),-12.40(\mathrm{~s}),-14.14(\mathrm{~s}),-14.45(\mathrm{~s}),-15.67(\mathrm{~s}),-16.71(\mathrm{~s}),-18.98(\mathrm{~s}) . \mathrm{ESI}^{+}-\mathrm{MS}$ : $\mathrm{C}_{22} \mathrm{H}_{30} \mathrm{EuN}_{4} \mathrm{O}_{9}[\mathrm{M}-\mathrm{BQ}+\mathrm{Li}+\mathrm{Na}]^{+} \mathrm{m} / z_{\text {calc }}: 581.0859 ; \mathrm{m} / z_{\text {found }}: 581.12683$.

\subsubsection{Eu. $\mathrm{L}^{2}$}

${ }^{1} \mathrm{H}-\mathrm{NMR}\left(500 \mathrm{MHz}, \mathrm{D}_{2} \mathrm{O}\right): \delta 33.45\left(\mathrm{~s}, \mathrm{H}_{\mathrm{a}-\mathrm{ax}}\right), 33.04\left(\mathrm{~s}, \mathrm{H}_{\mathrm{a}-\mathrm{ax}}\right), 26.57\left(\mathrm{~s}, \mathrm{H}_{\mathrm{a}-\mathrm{ax}}\right), 24.68$ (s, $\left.\mathrm{H}_{\mathrm{a}-\mathrm{ax}}\right), 13.16$ (s, $\left.\mathrm{H}_{\mathrm{a}-\mathrm{ax}}\right),-0.55(\mathrm{~s}),-0.85(\mathrm{~s}),-1.13\left(\mathrm{~s}, \mathrm{H}_{\mathrm{a}-\mathrm{eq}}\right),-2.00(\mathrm{~s}),-3.52(\mathrm{~s}),-4.19(\mathrm{~s}),-5.36(\mathrm{~s}),-6.38(\mathrm{~s}),-6.77(\mathrm{~s}$, $\left.\mathrm{H}_{\mathrm{b}-\mathrm{eq}}\right),-7.30(\mathrm{~s}),-7.94\left(\mathrm{~s}, \mathrm{H}_{\mathrm{b}-\mathrm{ax}}\right),-8.77(\mathrm{~s}),-8.95(\mathrm{~s}),-9.57(\mathrm{~s}),-10.36(\mathrm{~s}),-12.35(\mathrm{~s}),-14.09(\mathrm{~s}),-14.47$ $\left(\mathrm{s}, \mathrm{H}_{\mathrm{c}}\right),-15.72\left(\mathrm{~s}, \mathrm{H}_{\mathrm{c}^{\prime}}\right),-16.72(\mathrm{~s}),-18.99$ (s). ESI ${ }^{+}-\mathrm{MS}: \mathrm{C}_{38} \mathrm{H}_{54} \mathrm{Eu}_{2} \mathrm{~N}_{8} \mathrm{O}_{16}\left[\mathrm{M}-\mathrm{Eu} \mathrm{L}^{1}+2 \mathrm{H}\right]^{2+} \mathrm{m} / \mathrm{z}_{\mathrm{calc}}$ : $553.09497 ; \mathrm{m} / \mathrm{z}_{\text {found }}: 553.09433$. 


\subsubsection{Eu. $\mathrm{L}^{3}$}

${ }^{1} \mathrm{H}-\mathrm{NMR}\left(500 \mathrm{MHz}, \mathrm{D}_{2} \mathrm{O}\right): \delta 32.81\left(\mathrm{~s}, \mathrm{H}_{\mathrm{a}-\mathrm{ax}}\right), 26.48\left(\mathrm{~s}, \mathrm{H}_{\mathrm{a}-\mathrm{ax}}\right), 24.55\left(\mathrm{~s}, \mathrm{H}_{\mathrm{a}-\mathrm{ax}}\right), 12.58\left(\mathrm{~s}, \mathrm{H}_{\mathrm{a}-\mathrm{ax}}\right),-0.50(\mathrm{~s})$, $-1.26\left(\mathrm{~s}, \mathrm{H}_{\mathrm{a}-\mathrm{eq}}\right),-4.07(\mathrm{~s}),-5.33(\mathrm{~s}),-6.87\left(\mathrm{~s}, \mathrm{H}_{\mathrm{b}-\mathrm{eq}}\right),-7.68\left(\mathrm{~s}, \mathrm{H}_{\mathrm{b}-\mathrm{ax}}\right),-8.88(\mathrm{~s}),-9.63(\mathrm{~s}),-10.37(\mathrm{~s}),-12.28$ $(\mathrm{s}),-14.28\left(\mathrm{~s}, \mathrm{H}_{\mathrm{c}}\right),-15.28\left(\mathrm{~s}, \mathrm{H}_{\mathrm{c}^{\prime}}\right),-16.71(\mathrm{~s}),-18.93(\mathrm{~s}) . \mathrm{ESI}^{+}-\mathrm{MS}: \mathrm{C}_{28} \mathrm{H}_{35} \mathrm{EuN}_{4} \mathrm{O}_{10}\left[\mathrm{M}-2 \mathrm{BQ}+\mathrm{Li}+\mathrm{Na}^{+}\right.$ $m / z_{\text {calc }}: 740.15600 ; m / z_{\text {found }}: 581.0859$.

\subsection{4. $\mathrm{Tb} . \mathrm{L}^{\mathbf{1}}$}

${ }^{1} \mathrm{H}-\mathrm{NMR}\left(500 \mathrm{MHz}, \mathrm{D}_{2} \mathrm{O}\right): \delta 158.10$ (s), 141.43 (s), 82.28 (s), -15.97 (s), -21.11 (s), -27.08 (s), -45.67 (s), $-65.83(\mathrm{~s}),-89.49(\mathrm{~s}),-94.24(\mathrm{~s}),-98.91(\mathrm{~s}),-114.70(\mathrm{~s}),-155.75(\mathrm{~s}),-184.30(\mathrm{~s}),-307.81(\mathrm{~s}),-334.80(\mathrm{~s})$. $\mathrm{ESI}^{+}$-MS: $\mathrm{C}_{22} \mathrm{H}_{30} \mathrm{TbN}_{4} \mathrm{O}_{9}[\mathrm{M}-\mathrm{BQ}+\mathrm{Li}+\mathrm{Na}]^{+} \mathrm{m} / z_{\text {calc }}: 589.09059 ; m / z_{\text {found }} 589.13109$.

\subsection{5. $\mathrm{Tb} \cdot \mathrm{L}^{2}$}

${ }^{1} \mathrm{H}-\mathrm{NMR}\left(500 \mathrm{MHz}, \mathrm{D}_{2} \mathrm{O}\right): \delta 259.21$ (s), 136.45 (s), 82.55 (s), -15.86 (s), -26.89 (s), -37.37 (s), -41.28 (s), $-45.65(\mathrm{~s}),-65.68(\mathrm{~s}),-65.90(\mathrm{~s}),-95.32(\mathrm{~s}),-98.89(\mathrm{~s}),-114.68(\mathrm{~s}),-155.90(\mathrm{~s}),-184.35(\mathrm{~s}),-227.85(\mathrm{~s})$, -388.21 (s). $\mathrm{ESI}^{+}-\mathrm{MS}: \mathrm{C}_{38} \mathrm{H}_{54} \mathrm{~Tb}_{2} \mathrm{~N}_{8} \mathrm{O}_{16}\left[\mathrm{M}-\mathrm{Tb} . \mathrm{L}^{1}+2 \mathrm{H}\right]^{2+} \mathrm{m} / \mathrm{z}_{\text {calc }}: 561.10046 ; \mathrm{m} / \mathrm{z}_{\text {found }}: 561.09983$.

\subsection{6. $\mathrm{Tb} . \mathrm{L}^{3}$}

${ }^{1} \mathrm{H}-\mathrm{NMR}\left(500 \mathrm{MHz}, \mathrm{D}_{2} \mathrm{O}\right): \delta 257.88$ (s), $157.74(\mathrm{~s}), 141.11(\mathrm{~s}), 135.48$ (s), $82.26(\mathrm{~s}),-15.81(\mathrm{~s}),-27.23$ (s), $-37.31(\mathrm{~s}),-41.46(\mathrm{~s}),-45.59(\mathrm{~s}),-65.80(\mathrm{~s}),-95.02(\mathrm{~s}),-98.57(\mathrm{~s}),-114.58(\mathrm{~s}),-155.58(\mathrm{~s}),-184.08(\mathrm{~s})$. ESI ${ }^{+}-\mathrm{MS}: \mathrm{C}_{28} \mathrm{H}_{35} \mathrm{TbN}_{4} \mathrm{O}_{10}[\mathrm{M}-2 \mathrm{BQ}+2 \mathrm{H}]^{+} \mathrm{m} / \mathrm{z}_{\text {calc }}: 561.10046 ; \mathrm{m} / \mathrm{z}_{\text {found }} 561.09930$.

\subsection{Oxidation Tests}

In a typical experiment, hydroquinone or alpha-tocopherol were dissolved in the solvent (HEPES $0.1 \mathrm{M} \mathrm{pH} 7.2+1 \%$ Triton X-100) to concentration $0.04 \mathrm{M}$ in a small vial. When HEPES buffer was employed, hydroquinone was first dissolved in the smallest amount of EtOH possible and HEPES buffer with $1 \%$ Triton X-100 was added. If necessary, the mixture was sonicated in a water bath to favour solubilisation. The test compound (hydroquinone or $\alpha$-tocopherol) was added to the mixture at room temperature and stirred for $5 \mathrm{~min}$ before withdrawal of a sample and dilution to $0.1 \mathrm{mM}$ in a volumetric flask and transfer of $3 \mathrm{~mL}$ of sample in a cuvette. The absorption measurements were acquired scanning the wavelength range 800-200 $\mathrm{nm}$.

The complex was dissolved in HEPES buffer $0.1 \mathrm{M}$ at $\mathrm{pH} 7.2$ to concentration $0.04 \mathrm{M}$. $75 \mu \mathrm{L}$ of solution were withdrawn, transferred in a cuvette and brought to volume $(3 \mathrm{~mL})$ by addition of $2.925 \mathrm{~mL}$ of $\mathrm{H}_{2} \mathrm{O}$ to have a resulting $1 \mathrm{mM}$ concentration. $\mathrm{HOCl}$ (from $\mathrm{HOCl} 5 \%$ w/v up to 25 equivalents for Eu. $\mathbf{L}^{\mathbf{1}}, 38$ equivalents for Eu. $\mathbf{L}^{\mathbf{2}}, 28$ equivalents for Eu. $\mathbf{L}^{3}, 20$ equivalents for Tb. $\mathbf{L}^{\mathbf{1}}, 22$ equivalents for $\mathrm{Tb} . \mathrm{L}^{2}, 28$ equivalents for $\mathrm{Tb} . \mathrm{L}^{3}$ ) was added to the mixture at room temperature and the cuvette was intermittently shaken for $5 \mathrm{~min}$. After this time, the measurements were obtained.

\section{Conclusions}

Mono-and diesters of hydroquinone were synthesised and coupled to cyclen-based carboxylate ligands. Three different ligands $\mathbf{L}^{1}, \mathbf{L}^{2}$, and $\mathbf{L}^{3}$ were prepared and used to form europium(III) and terbium(III) complexes: $\mathbf{L n} \cdot \mathbf{L}^{1}$, $\mathbf{L}$. $\mathbf{L}^{2}$, and $\mathbf{L n} . \mathbf{L}^{3}$. In total, six new complexes of europium(III) and terbium(III) were synthesized, characterised and tested for their activity towards the $\mathrm{HOCl}$ using a testbed developed in order to give reproducible results when exploring oxidation reactions. The testbed is based on a HEPES buffer at $\mathrm{pH} 7.2$, with Triton-X added to ensure solubility of lipophilic systems. 


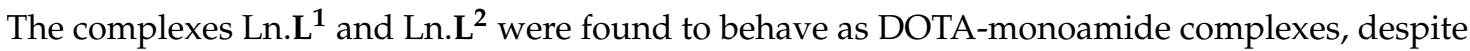
being mono-esters. NMR and luminescence spectra showed that $\mathbf{L n} \cdot \mathbf{L}^{\mathbf{1}}$ is more flexible than diester $\mathbf{L n} \cdot \mathbf{L}^{2}$. Ln. $\mathbf{L}^{3}$ is a DOTA-diester, and the added steric bulk resulted in a more rigid structure. All investigated complexes reacted selectively with $\mathrm{HOCl}$. The reaction resulted in that the esters were hydrolysed, converting all complexes via one or two steps to [Ln.DOTA $]^{-}$. The conversion could be followed using luminescence spectroscopy with a direct intensity-based or a ratiometric readout. Independent of the stoichiometry of the reaction, in exceed of 15 equivalents were needed to fully convert the probes to [Ln.DOTA $]^{-}$. Thus, we conclude that incorporating the hydroquinone unit in a lanthanide complex reduces the reactivity towards reactive oxygen species. Additionally, the reactivity of the hydroquinone esters is dictated by the structure of the lanthanide complex, as exemplified by the activity of the di-ester in $\mathbf{L n} \cdot \mathrm{L}^{2}$ and mono-esters in $\mathbf{L n} \cdot \mathrm{L}^{3}$. The next step is to incorporate an efficient antenna and a hydroquinone caging unit in a single lanthanide(III) complex.

Supplementary Materials: The following are available online, NMR spectra, mass spectra, absorption spectra, time-resolved emission profiles, and luminescence spectra.

Author Contributions: Conceptualization E.D.G. and T.J.S.; Methodology, E.D.G. and T.J.S.; Formal Analysis, E.D.G.; Resources, T.J.S.; Writing-Original Draft Preparation, E.D.G. and T.J.S.; Writing-Review \& Editing, E.D.G. and T.J.S.; Supervision T.J.S.; Project Administration E.D.G. All authors have read and agreed to the published version of the manuscript.

Funding: This work was supported by the University of Copenhagen, the Novo Nordisk Foundation, Carlsbergfondet, and the Villum Foundation (grant\#14922).

Acknowledgments: We thank the University of Copenhagen, Novo Nordisk Foundation, Carlsbergfondet, and the Villum Foundation (grant\#14922) for support and Lea Gundorff Nielsen for valuable help preparing the manuscript.

Conflicts of Interest: The authors declare no conflict of interest.

\section{References}

1. Winterbourn, C.C. Reconciling the chemistry and biology of reactive oxygen species. Nat. Chem. Biol. 2008, 4, 278-286. [CrossRef] [PubMed]

2. Valko, M.; Leibfritz, D.; Moncol, J.; Cronin, M.T.; Mazur, M.; Telser, J. Free radicals and antioxidants in normal physiological functions and human disease. Int. J. Biochem. Cell Biol. 2007, 39, 44-84. [CrossRef] [PubMed]

3. Nimse, S.B.; Pal, D. Free radicals, natural antioxidants, and their reaction mechanisms. RSC Adv. 2015, 5, 27986-28006. [CrossRef]

4. Andina, D.; Leroux, J.C.; Luciani, P. Ratiometric fluorescent probes for the detection of reactive oxygen species. Chemistry 2017, 23, 13549-13573. [CrossRef]

5. Dickinson, B.C.; Chang, C.J. Chemistry and biology of reactive oxygen species in signaling or stress responses. Nat. Chem. Biol. 2011, 7, 504-511. [CrossRef] [PubMed]

6. Murphy, M.P.; Holmgren, A.; Larsson, N.G.; Halliwell, B.; Chang, C.J.; Kalyanaraman, B.; Rhee, S.G.; Thornalley, P.J.; Partridge, L.; Gems, D.; et al. Unraveling the biological roles of reactive oxygen species. Cell Metab. 2011, 13, 361-366. [CrossRef] [PubMed]

7. Ray, P.D.; Huang, B.W.; Tsuji, Y. Reactive oxygen species (ROS) homeostasis and redox regulation in cellular signaling. Cell. Signal. 2012, 24, 981-990. [CrossRef] [PubMed]

8. Gomes, A.; Fernandes, E.; Lima, J.L.F.C. Fluorescence probes used for detection of reactive oxygen species. J. Biochem. Biophys. Methods 2005, 65, 45-80. [CrossRef]

9. Jiang, X.; Wang, L.; Carroll, S.L.; Chen, J.; Wang, M.C.; Wang, J. Challenges and opportunities for small-molecule fluorescent probes in redox biology applications. Antioxid. Redox Signal. 2018, 29, 518-540. [CrossRef]

10. Finkel, T. Signal transduction by reactive oxygen species. J. Cell Biol. 2011, 194, 7-15. [CrossRef]

11. Zhang, R.; Song, B.; Yuan, J. Bioanalytical methods for hypochlorous acid detection: Recent advances and challenges. TrAC Trends Anal. Chem. 2018, 99, 1-33. [CrossRef]

12. Chen, X.; Tian, X.; Shin, I.; Yoon, J. Fluorescent and luminescent probes for detection of reactive oxygen and nitrogen species. Chem. Soc. Rev. 2011, 40, 4783-4804. [CrossRef] [PubMed] 
13. Xiao, Y.; Ye, Z.; Wang, G.; Yuan, J. A ratiometric luminescence probe for highly reactive oxygen species based on lanthanide complexes. Inorg. Chem. 2012, 51, 2940-2946. [CrossRef] [PubMed]

14. Haugland, R.P. Handbook of Fluorescent Probes and Research Chemicals, 11th ed.; Molecular Probes: Eugene, OR, USA, 2010.

15. Wardman, P. Fluorescent and luminescent probes for measurement of oxidative and nitrosative species in cells and tissues: Progress, pitfalls, and prospects. Free Radic. Biol. Med. 2007, 43, 995-1022. [CrossRef]

16. Kalyanaraman, B.; Darley-Usmar, V.; Davies, K.J.; Dennery, P.A.; Forman, H.J.; Grisham, M.B.; Mann, G.E.; Moore, K.; Roberts, L.J., 2nd; Ischiropoulos, H.; et al. Measuring reactive oxygen and nitrogen species with fluorescent probes: Challenges and limitations. Free Radic. Biol. Med. 2012, 52, 1-6. [CrossRef]

17. Chan, J.; Dodani, S.C.; Chang, C.J. Reaction-based small-molecule fluorescent probes for chemoselective bioimaging. Nat. Chem. 2012, 4, 973-984. [CrossRef]

18. Bunzli, J.C.; Piguet, C. Taking advantage of luminescent lanthanide ions. Chem. Soc. Rev. 2005, 34, 1048-1077. [CrossRef]

19. Zwier, J.M.; Bazin, H.; Lamarque, L.; Mathis, G. Luminescent lanthanide cryptates: From the bench to the bedside. Inorg. Chem. 2014, 53, 1854-1866. [CrossRef]

20. Heffern, M.C.; Matosziuk, L.M.; Meade, T.J. Lanthanide probes for bioresponsive imaging. Chem. Rev. 2014, 114, 4496-4539. [CrossRef]

21. Stasiuk, G.J.; Long, N.J. The ubiquitous DOTA and its derivatives: The impact of 1,4,7,10-tetraazacyclododecane-1,4,7,10-tetraacetic acid on biomedical imaging. Chem. Commun. (Camb. Engl.) 2013, 49, 2732-2746. [CrossRef]

22. Nielsen, L.G.; Junker, A.K.R.; Sørensen, T.J. Composed in the f-block: Solution structure and function of kinetically inert lanthanide(iii) complexes. Dalton Trans. 2018, 47, 10360-10376. [CrossRef] [PubMed]

23. Sørensen, T.J.; Faulkner, S. Multimetallic lanthanide complexes: Using kinetic control to define complex multimetallic arrays. Acc. Chem. Res. 2018, 51, 2493-2501. [CrossRef] [PubMed]

24. Brücher, E.; Baranyai, Z.; Tircsó, G. The future of biomedical imaging: Synthesis and chemical properties of the DTPA and DOTA derivative ligands and their complexes. In Biomedical Imaging: The Chemistry of Labels, Probes, and Contrast Agents; Braddock, M., Ed.; Royal Society of Chemistry: Cambridge, UK, 2012; Chapter 5.2, pp. 208-260. [CrossRef]

25. Parker, D. Luminescent lanthanide sensors for $\mathrm{pH}, \mathrm{pO} 2$ and selected anions. Coord. Chem. Rev. 2000, 205, 109-130. [CrossRef]

26. Junker, A.K.R.; Tropiano, M.; Faulkner, S.; Sørensen, T.J. Kinetically inert lanthanide complexes as reporter groups for binding of potassium by 18-crown-6. Inorg. Chem. 2016, 55, 12299-12308. [CrossRef]

27. Ye, Z.; Wang, G.; Chen, J.; Fu, X.; Zhang, W.; Yuan, J. Development of a novel terbium chelate-based luminescent chemosensor for time-resolved luminescence detection of intracellular Zn2+ ions. Biosens. Bioelectron. 2010, 26, 1043-1048. [CrossRef] [PubMed]

28. Liu, D.; Tang, K.; Liu, W.; Su, C.; Yan, X.; Tan, M.; Tang, Y. A novel luminescent chemosensor for detecting $\mathrm{Hg}(2+)$ based on the pendant benzo crown ether terbium complex. Dalton Trans. 2010, 39, 9763-9765. [CrossRef] [PubMed]

29. Carr, R.; Puckrin, R.; McMahon, B.K.; Pal, R.; Parker, D.; Pålsson, L.O. Induced circularly polarized luminescence arising from anion or protein binding to racemic emissive lanthanide complexes. Methods Appl. Fluoresc. 2014, 2. [CrossRef]

30. Weitz, E.A.; Chang, J.Y.; Rosenfield, A.H.; Pierre, V.C. A selective luminescent probe for the direct time-gated detection of adenosine triphosphate. J. Am. Chem. Soc. 2012, 134, 16099-16102. [CrossRef]

31. Hewitt, S.H.; Parris, J.; Mailhot, R.; Butler, S.J. A continuous luminescence assay for monitoring kinase activity: Signalling the ADP/ATP ratio using a discrete europium complex. Chem. Commun. (Camb. Engl.) 2017, 53, 12626-12629. [CrossRef]

32. Mailhot, R.; Traviss-Pollard, T.; Pal, R.; Butler, S.J. Cationic europium complexes for visualizing fluctuations in mitochondrial atp levels in living cells. Chem. A Eur. J. 2018, 24, 10745-10755. [CrossRef]

33. Hewitt, S.H.; Ali, R.; Mailhot, R.; Antonen, C.R.; Dodson, C.A.; Butler, S.J. A simple, robust, universal assay for real-time enzyme monitoring by signalling changes in nucleoside phosphate anion concentration using a europium(iii)-based anion receptor. Chem. Sci. 2019, 10, 5373-5381. [CrossRef] 
34. Hewitt, S.H.; Macey, G.; Mailhot, R.; Elsegood, M.R.J.; Duarte, F.; Kenwright, A.M.; Butler, S.J. Tuning the anion binding properties of lanthanide receptors to discriminate nucleoside phosphates in a sensing array. Chem. Sci. 2020. [CrossRef]

35. Page, S.E.; Wilke, K.T.; Pierre, V.C. Sensitive and selective time-gated luminescence detection of hydroxyl radical in water. Chem. Commun. (Camb. Engl.) 2010, 46, 2423-2425. [CrossRef]

36. Lippert, A.R.; Gschneidtner, T.; Chang, C.J. Lanthanide-based luminescent probes for selective time-gated detection of hydrogen peroxide in water and in living cells. Chem. Commun. (Camb. Engl.) 2010, 46, 7510-7512. [CrossRef]

37. Smith, D.G.; McMahon, B.K.; Pal, R.; Parker, D. Live cell imaging of lysosomal pH changes with pH responsive ratiometric lanthanide probes. Chem. Commun. (Camb. Engl.) 2012, 48, 8520-8522. [CrossRef]

38. Liu, M.; Ye, Z.; Xin, C.; Yuan, J. Development of a ratiometric time-resolved luminescence sensor for $\mathrm{pH}$ based on lanthanide complexes. Anal. Chim. Acta 2013, 761, 149-156. [CrossRef]

39. Breen, C.; Pal, R.; Elsegood, M.R.J.; Teat, S.J.; Iza, F.; Wende, K.; Buckley, B.R.; Butler, S.J. Time-resolved luminescence detection of peroxynitrite using a reactivity-based lanthanide probe. Chem. Sci. 2020. [CrossRef]

40. Wolfbeis, O.S.; Dürkop, A.; Wu, M.; Lin, Z. A europium-ion-based luminescent sensing probe for hydrogen peroxide. Angew. Chem. Int. Ed. 2002, 41, 4495-4498. [CrossRef]

41. Hong, J.; Zhuang, Y.; Ji, X.; Guo, X. A long-lived luminescence and EPR bimodal lanthanide-based probe for free radicals. Analyst 2011, 136, 2464-2470. [CrossRef]

42. Pershagen, E.; Nordholm, J.; Borbas, K.E. Luminescent lanthanide complexes with analyte-triggered antenna formation. J. Am. Chem. Soc. 2012, 134, 9832-9835. [CrossRef]

43. Kaur, A.; Kolanowski, J.L.; New, E.J. Reversible fluorescent probes for biological redox states. Angew. Chem. 2016, 55, 1602-1613. [CrossRef]

44. Shuvaev, S.; Starck, M.; Parker, D. Responsive, water-soluble Europium(III) luminescent probes. Chem. A Eur. J. 2017, 23, 9974-9989. [CrossRef]

45. Szijjarto, C.; Pershagen, E.; Ilchenko, N.O.; Borbas, K.E. A versatile long-wavelength-absorbing scaffold for Eu-based responsive probes. Chemistry 2013, 19, 3099-3109. [CrossRef]

46. Cui, G.; Ye, Z.; Chen, J.; Wang, G.; Yuan, J. Development of a novel terbium(III) chelate-based luminescent probe for highly sensitive time-resolved luminescence detection of hydroxyl radical. Talanta 2011, 84, 971-976. [CrossRef]

47. Liu, X.; Guo, L.; Song, B.; Tang, Z.; Yuan, J. Development of a novel europium complex-based luminescent probe for time-gated luminescence imaging of hypochlorous acid in living samples. Methods Appl. Fluoresc. 2017, 5. [CrossRef]

48. Peterson, K.L.; Margherio, M.J.; Doan, P.; Wilke, K.T.; Pierre, V.C. Basis for sensitive and selective time-delayed luminescence detection of hydroxyl radical by lanthanide complexes. Inorg. Chem. 2013, 52, 9390-9398. [CrossRef]

49. Tropiano, M.; Kilah, N.L.; Morten, M.; Rahman, H.; Davis, J.J.; Beer, P.D.; Faulkner, S. Reversible luminescence switching of a redox-active ferrocene-europium dyad. J. Am. Chem. Soc. 2011, 133, 11847-11849. [CrossRef]

50. Lou, Z.; Li, P.; Pan, Q.; Han, K. A reversible fluorescent probe for detecting hypochloric acid in living cells and animals: Utilizing a novel strategy for effectively modulating the fluorescence of selenide and selenoxide. Chem. Commun. (Camb. Engl.) 2013, 49, 2445-2447. [CrossRef]

51. Koide, Y.; Kawaguchi, M.; Urano, Y.; Hanaoka, K.; Komatsu, T.; Abo, M.; Terai, T.; Nagano, T. A reversible near-infrared fluorescence probe for reactive oxygen species based on Te-rhodamine. Chem. Commun. (Camb. Engl.) 2012, 48, 3091-3093. [CrossRef]

52. Hopper, L.E.; Allen, M.J. Rapid synthesis of 1,7-bis(t-butoxycarbonylmethyl)-1,4,7,10-tetraazacyclododecane (DO2A-t-Bu ester). Tetrahedron Lett. 2014, 55, 5560-5561. [CrossRef]

53. Nielsen, L.G.; Sørensen, T.J. Including and declaring structural fluctuations in the study of Lanthanide(III) coordination chemistry in solution. Inorg. Chem. 2019. [CrossRef]

54. Beeby, A.; Clarkson, I.M.; Dickins, R.S.; Faulkner, S.; Parker, D.; Royle, L.; de Sousa, A.S.; Williams, J.A.G.; Woods, M. Non-radiative deactivation of the excited states of europium, terbium and ytterbium complexes by proximate energy-matched $\mathrm{OH}, \mathrm{NH}$ and $\mathrm{CH}$ oscillators: An improved luminescence method for establishing solution hydration states. J. Chem. Soc. Perkin Trans. 1999, 2, 493-504. [CrossRef] 
55. Tropiano, M.; Blackburn, O.A.; Tilney, J.A.; Hill, L.R.; Just Sørensen, T.; Faulkner, S. Exploring the effect of remote substituents and solution structure on the luminescence of three lanthanide complexes. J. Lumin. 2015, 167, 296-304. [CrossRef]

56. Horrocks, W.D.; Sudnick, D.R. Lanthanide ion probes of structure in biology. Laser-induced luminescence decay constants provide a direct measure of the number of metal-coordinated water molecules. J. Am. Chem. Soc. 1979, 101, 334-340. [CrossRef]

Sample Availability: Not available.

(C) 2020 by the authors. Licensee MDPI, Basel, Switzerland. This article is an open access article distributed under the terms and conditions of the Creative Commons Attribution (CC BY) license (http://creativecommons.org/licenses/by/4.0/). 